J. Environ. Sci.

Institute of Environmental Studies and Research - Ain Shams University

\title{
EVALUATION OF EL-GHARBIA DRAIN WATER QUALITY TO INCREASE BENEFITS FROM IT
}

El-Sherbiny, H. A. ${ }^{(1)}$; EL-Kassas, H. $^{(2)}$ and El-Saadi A.M. ${ }^{(1)}$

1) Drainage Research Institute, National Water Research Center 2) Institute of Environmental Studies and Research, Ain Shams University

\begin{abstract}
Water quality control is a major issue for Egypt where the severity of present water quality problems varies among different water bodies. Managing the water quality of Gharbia drain is an important issue to ensure suitability of drain water for reuse in irrigation. The assessment of the drain water enhanced substantially by the use of water quality simulation model (HEC-RAS) to investigate environmental impacts based on the principle of treatment. The study activities based on field measurements, laboratory analysis and data interpretation for Biological Oxygen Demand (BOD), Dissolved Oxygen (DO), Total Nitrogen, Organic Nitrogen, Ammonia, Nitrate, Nitrite, Total Phosphorus, Organic Phosphorus and Ortho Phosphate. The pollution load calculated for the point sources that have the most negatively impact on the water quality of the drain were identified and six different scenarios were developed (decreasing the concentration by $25 \%$ and $50 \%$ from its original value to improve water quality of the drain) using water quality modeling (HEC-RAS model).

The results indicate that the sixth scenario in which 50\% improvement in water quality of the point sources of samatay \& P.S. 3,4,5,6 due to the increase of wastewater treatment plants efficiency is the best scenario followed by the fourth which propose enhancement in the wastewater plants that are in the reach of Samatay and (5) Pump stations, which results in improving the water quality at these point sources by $50 \%$. And fifth scenario which proposes the enhancement in the wastewater treatment plants that are in the catchment of stations $(6,3,4)$ has been improved the water quality by $50 \%$.
\end{abstract}

Keywords: Gharbia drain, HEC-RAS, Drain water reuse, Water Quality. 


\section{INTRODUCTION}

Egypt needs to increase and sustain productivity of irrigated agriculture land in Egypt, the present per capita share of water is approximately 603 $\mathrm{m}^{3} / \mathrm{yr}$ today, while the per capita share of cultivated land is as low as 0.08 acre (DRI, 1995). Based on the measures towards water resources management, Egypt is also facing serious challenges such as deterioration of water quality and the growing demand-supply gap (DRI, $1997 \mathrm{a}: \mathrm{b})$. Increased industrial growth, together with intensified agriculture, has put a direct impact on the quality. Thus, availability of water became constrained by its degraded quality, which limited its use for specific purposes. Industrial activities, as well as urban centers, negatively affect the water quality of neighboring water bodies as wastewater is dumped into them without proper treatment.

As a non-conventional water resource, agricultural drain water reuse has become an important source of irrigation water in Egypt. It is well developed and prepared as a national policy (NWRP, 2005). Gharbia main drain system is one of the largest drain systems in the Nile Delta and valley. It is located in the central part of Middle Nile Delta. The area served by the drain is about 460,000 acres. Around one billion cubic meter per year is reused from the drain in irrigation purposes (DRI, 2000). It is a considerable amount of water compared to total reuse in Egypt. This is in addition to the large quantity of unofficial drain use which puts the Gharbia drain in the highest priority list for protection from pollution.

The assessment and management of the drain water quantity and quality can be enhanced substantially by the use of water quality simulation model (HEC-RAS) to investigate environmental interventions based on the principle 
of treatment. The Hydrologic Engineering Center River Analysis System (HEC-RAS) is intended for calculating water surface profiles for steady gradually varied flow in nature or man-made channels. The software allows performing one-dimensional steady, unsteady flow hydraulics, sediment transport/mobile bed computations, and water temperature modeling through a full network of open channels.

The objective of this study is to develop an assessment practice for water quality of the Gharbia main drain system. The assessment and management of water quantity and quality were carried out through water quality simulation model (HEC-RAS) to investigate environmental interventions based on the principle of treatment. The use of the mathematical model will support drain water management and maximize the reuse of drain water of acceptable quality. More specific objectives are as follows:

- Enhancing research capacity to respond to the decision makers for management support of drain water quality issues in Gharbia drain catchment.

- Using water quality model (HEC-RAS) to investigate water quantity/quality objectives and ensure efficient drain water reuse in the catchment.

\section{MATERIALS AND METHODS}

The methodology for this study is based on: (a) Assessment of water quality of Gharbia drain system including estimation of pollution loads, and (b) Developing different scenarios of interventions using water quality modeling. 
The methodology initiated with conducting field visits across the drain and monitored sources of pollution these locations are chosen according to the noticeable changes expected in water quality as shown in figures (1 and 2) due to contributions from pumping stations into the drain.

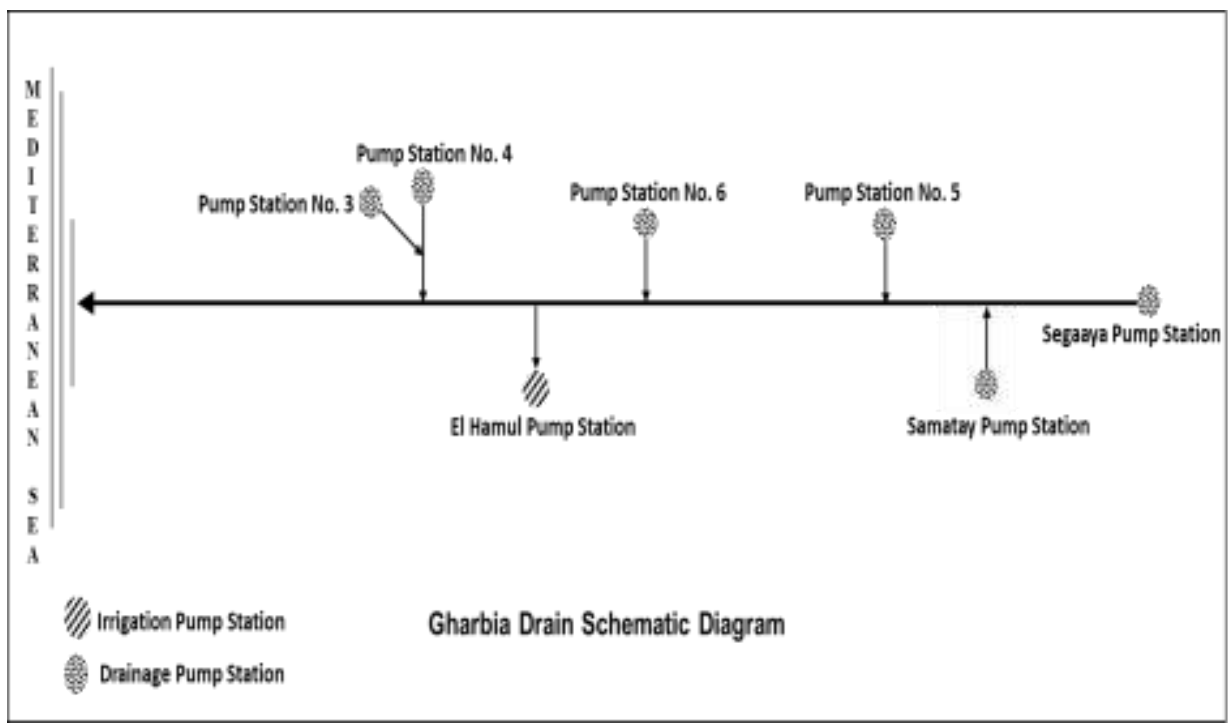

Figure (1): Schematic diagram for El-Gharbia drain system. 


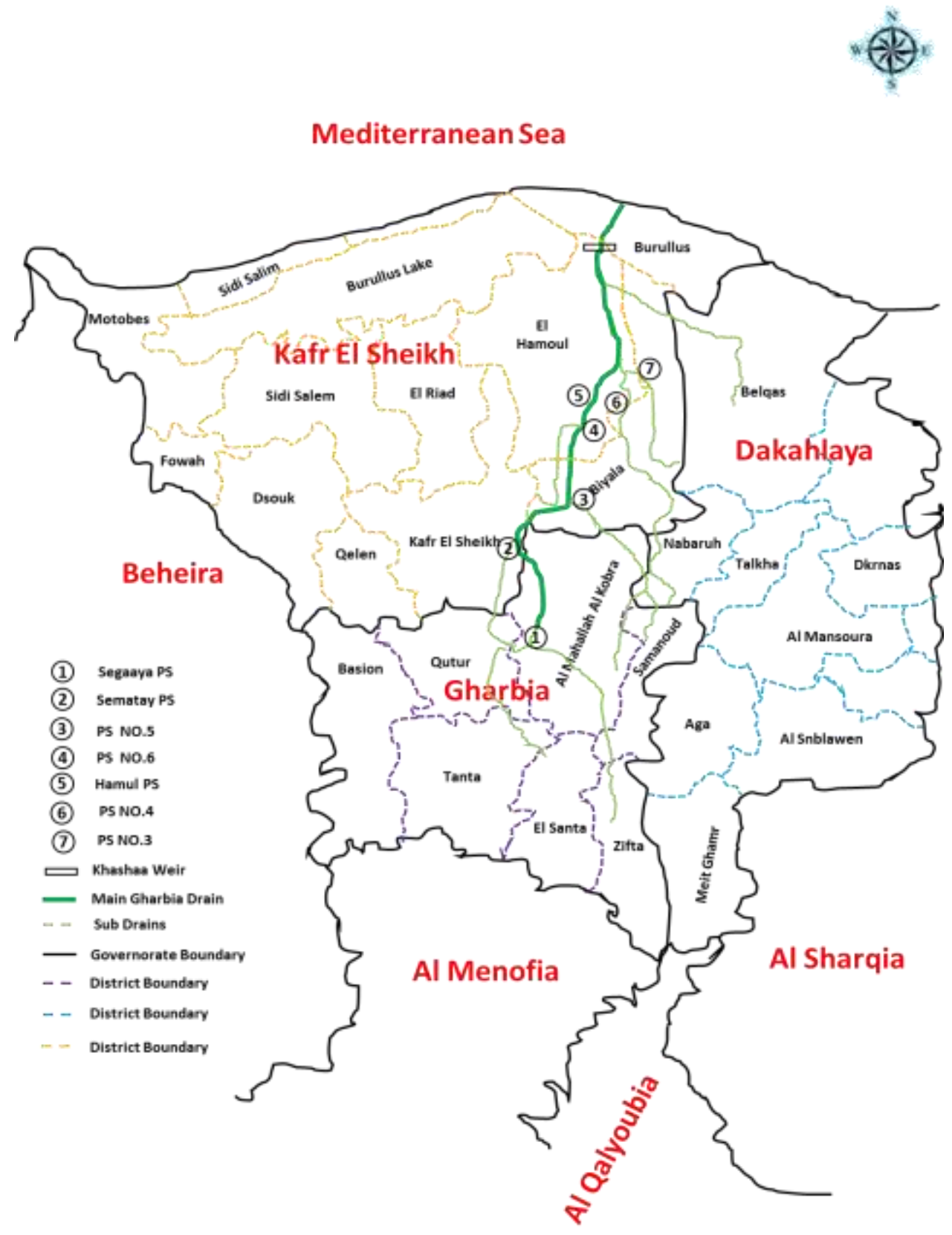

Figure (2): El-Gharbia drain system Layout 
After delivering the water samples to laboratory, it was analyzed for the physical and chemicals properties of the selective water quality parameters according to the standard methods mentioned in (Standard Methods for Examination of Water \& Wastewater, 20 ${ }^{\text {th }}$ ed., 1999). The water quality variables are as follows:

- Temperature.

- Biological Oxygen Demand (BOD).

- Dissolved Oxygen (DO).

- (Organic Nitrogen - Ammonia - Nitrate - Nitrite - Organic Phosphorus Ortho Phosphate).

Eight major sites in El-Gharbia drain system were selected as described in table (1). At least three independent samples were collected from each site in clean sterilized glass containers and stored in an iced cooler box and delivered immediately to the Central Laboratory for Environmental Quality Monitoring, National Water Research Center "CLEQM-NWRC" where it has been analyzed. 
J. Environ. Sci.

Institute of Environmental Studies and Research - Ain Shams University

Table (1): Sample Sites in El Gharbia Drain

\begin{tabular}{|c|c|}
\hline Location Name & Description \\
\hline \hline Segaaya P.S. & Segaaya drain outfall \\
\hline Sematay P.S. & Sematay drain outfall \\
\hline P.S.3 & $\begin{array}{c}\text { Lifting drain water to El-Gharbia main drain down } \\
\text { stream Hamule P.S. on Gharbia drain }\end{array}$ \\
\hline P.S.4 & $\begin{array}{c}\text { Lifting drain water downstream P.S.3 \& then to } \\
\text { Gharbia main drain }\end{array}$ \\
\hline P.S.5 & $\begin{array}{c}\text { Lifting drain water to Gharbia main drain downstream } \\
\text { sematay P.S. on Gharbia drain }\end{array}$ \\
\hline P.S.6 & $\begin{array}{c}\text { Lifting drain water to Gharbia main drain downstream } \\
\text { P.S.5 on Gharbia drain }\end{array}$ \\
\hline $\begin{array}{c}\text { Sematay Segaaya } \\
\text { Mixing }\end{array}$ & \begin{tabular}{c} 
Water quality monitoring location \\
\hline Ezbet el-Nil Bridge
\end{tabular} \\
\hline Hamule P.S & $\begin{array}{c}\text { Mixing drain water from Gharbia main drain } \\
\text { downstream P.S.6 to Tira Canal on Gharbia drain }\end{array}$ \\
\hline
\end{tabular}

* P.S: Pump Station

According to Figures (1 and 2), Samatay pump station collects the drain water from the areas of Qotour, Kafr El-Sheikh and Mahalla al-Kubra with a total population of $1,251,528$, and area served of 28,775 feddans. The catchment is served by two WWTP(s) namely (Nemra El-Basal and Sakha) with a total design capacity of $103,000 \mathrm{~m}^{3}$ / day for the two plants, while the total sewage drain produced by this served area is $141,739 \mathrm{~m}^{3} /$ day with deficit up to $38,739 \mathrm{~m}^{3} /$ day or by the percentage of $38 \%$.

Pump Station 5 collects the drain water of Samanud, Mahalla, Biala and Hamoul areas with a total of 273 villages where the total population is $123,290,7$ inhabitants, the served area is 72,200 feddans, the catchment is served by a 6 WWTP(s) stations namely (Ziad, Hamoul, Dimitio, Ebshan, El- 
zfaran, El-Kolia and Beshbish) With a design capacity of $41400 \mathrm{~m}^{3}$ / day for the six plants, while the total sewage resulting from such area is 143,137 $\mathrm{m}^{3} /$ day with a deficit up to $101,737 \mathrm{~m}^{3} /$ day or $275 \%$.

Station 6 collects the drain water from Kafr El-Sheikh and El Hamoul areas. The total number of villages is 117 villages, the total population is 400,700 , the area served is 39,290 feddans, and the number of treatment plants in this area is two plants (Sidi Ghazi and Hamoul) with a design capacity of $27000 \mathrm{~m} 3 /$ day for both plants. The total sewage drain resulting from such area is $44011 \mathrm{~m}^{3}$ / day with a deficit up to 17011 or $63 \%$.

Pump stations (3 and 4) collect drain water from Belqas, Nabarouh, Bila and Hamoul areas. the total numbers of villages are 283 with a total population of 1036219 inhabitants, a serving area is 112670 and a number of treatment plants in this area are 4 plants (Messra Bilqas- Nabarouh, Kafr El Garida-Bella) with a design capacity of $520,000 \mathrm{~m}^{3} /$ day while the total sewage drain resulting from such area was $111,637 \mathrm{~m}^{3} /$ day with a deficit of up to $59,537 \mathrm{~m}^{3} /$ day or $114 \%$.

Estimation of the pollution loads to be used in the implementation of simulation that will be conducted by using the mathematical models:

The pollution Load can be calculated according to the following equation: Load= Concentration $(\mathrm{C}) \mathrm{X}$ Discharge $(\mathrm{Q})$

\section{Principles of Model Formulation:}

Basis: The bases for mathematical models are the fundamental physical and chemical laws, such as the laws of conservation of mass, energy, and momentum. 
Assumptions: It involves making as many simplifying assumptions as reasonable. The assumptions that are made should be carefully considered and listed. They impose limitations on the model that should always be kept in mind when evaluating its predicted results (Luyben, 1996).

Calibration: The HEC-RAS model was calibrated by adjusting the Manning's roughness coefficient to better match.

Verification: The verification can be obtained by designing experiments to test the validity of a dynamic model can sometimes be a real challenge and should be carefully thought out.

Scenarios: Proposing different scenarios by decreasing the concentration by $25 \%$ and $50 \%$. For selective point sources from its original value to improve water quality of the drain then testing these scenarios impact on the drain using water quality modeling (ie., HEC-RAS model). The Scenarios Schematic Diagram presented in figures (3, 4 and 5).

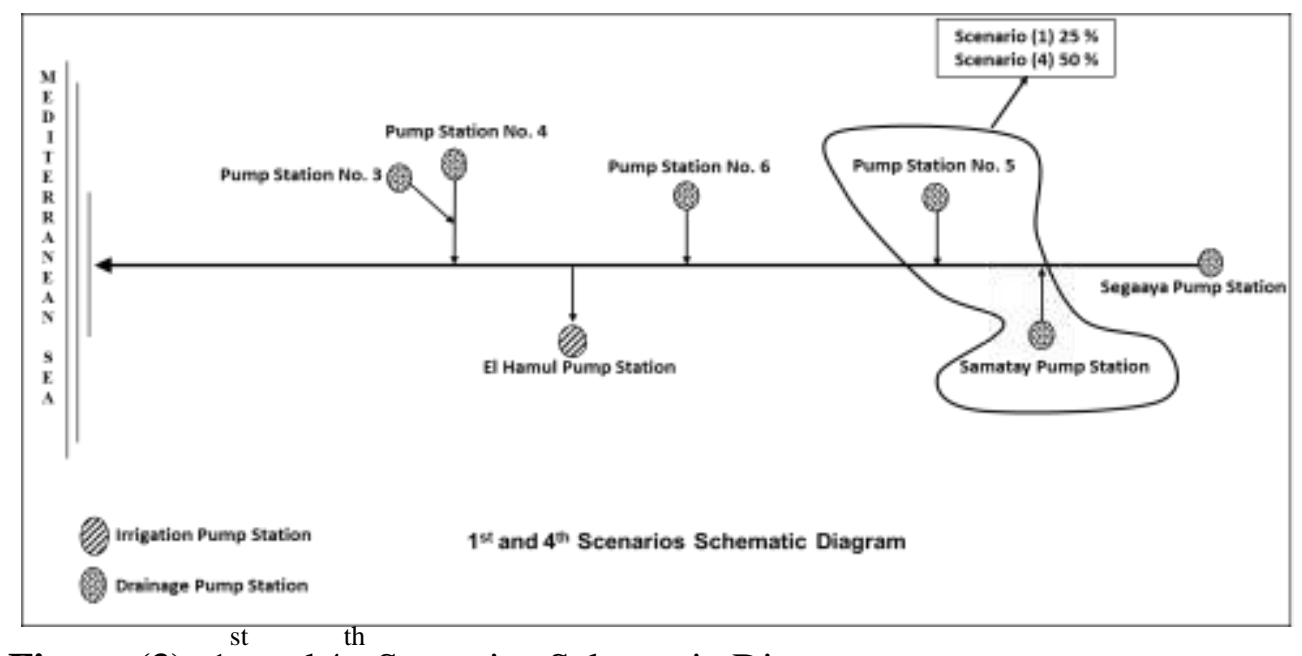

Figure (3): $1{ }^{\text {st }}$ and $4{ }^{\text {th }}$ Scenarios Schematic Diagram 


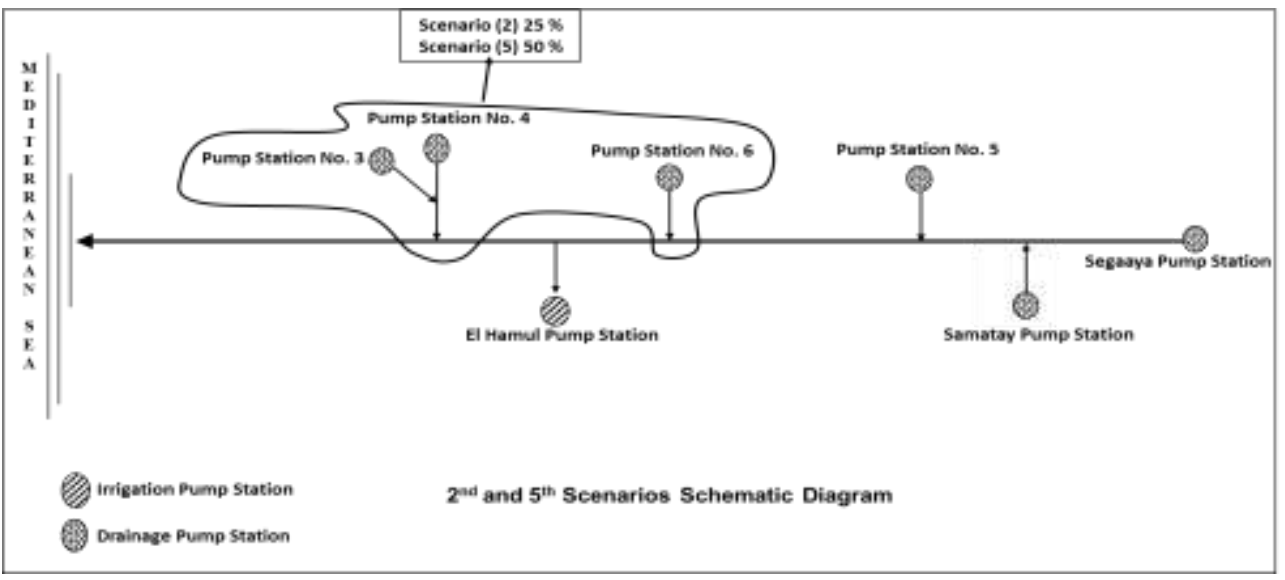

Figure (4): $2^{\text {nd }}$ and $5^{\text {th }}$ Scenarios Schematic Diagram

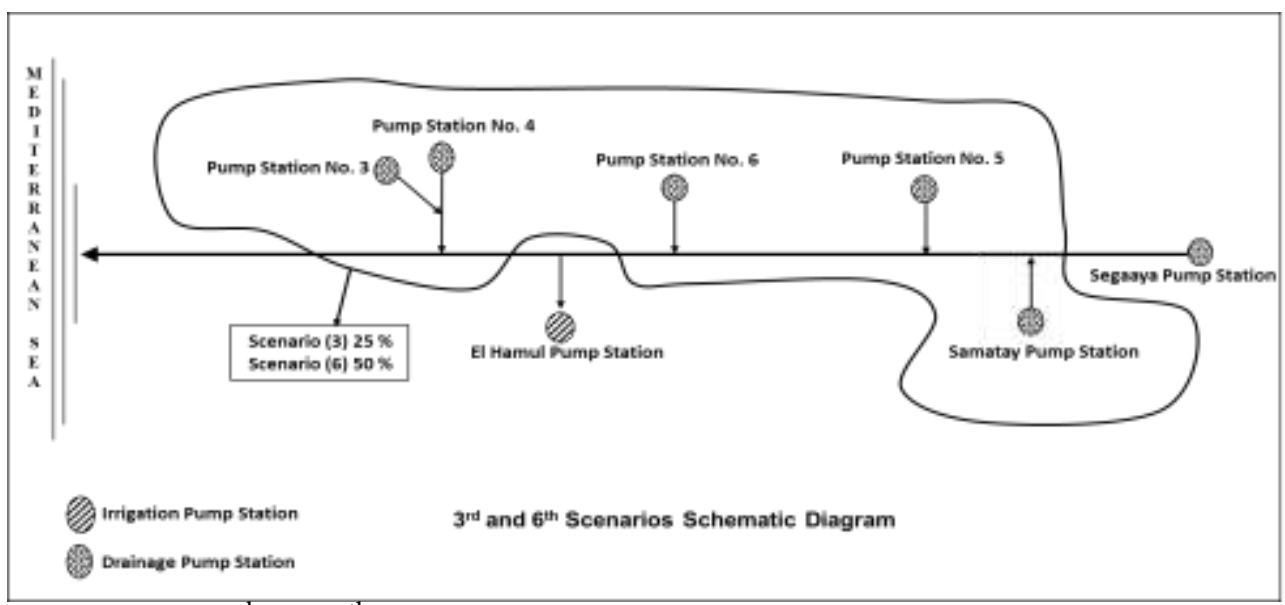

Figure (5): $3^{\text {rd }}$ and $6^{\text {th }}$ Scenarios Schematic Diagram

The First scenario: The First scenario is the improvement of the treatment plants at Samatay and Pump stations (5) catchments thus assumed improving the water quality at the point sourse by $25 \%$.

The second scenario: The second scenario is the improvement of treatment of the wastewater plants that are in the catchment of stations $4,3,6$, which assumed in improving water quality at these point sources by $25 \%$. 
The Third scenario: The third scenario is improving the treatment of the wastewater plants that are in the catchment of Samatay, (5, 6, 3 and 4) Pump stations, which assumed in improving water quality at these point sources by $25 \%$.

The Fourth scenario: The fourth scenario is the improving the treatment of the wastewater plants that are in the catchment of Samatay and Pump stations (5), which assumed in improving the water quality of these point sources by $50 \%$.

The Fifth scenario: The Fifth scenario is the improvement of the treatment of the wastewater stations that are in the reach of stations $(6,3,4)$, which assumed to improve the water quality at these point sources by $50 \%$.

The Sixth scenario: The Sixth scenario is the improvement of the treatment of the wastewater plants that are in the catchment of Samatay, pump Stations $(5,6,3$ and 4$)$, the assumed improvement of the water quality at these point sources is by $50 \%$.

\section{RESULTS}

Pollutant load has been calculated, the point sources have been classified according to its negative impact on the water quality of Gharbia drain as shown as Figure (6, 7 and 8). 


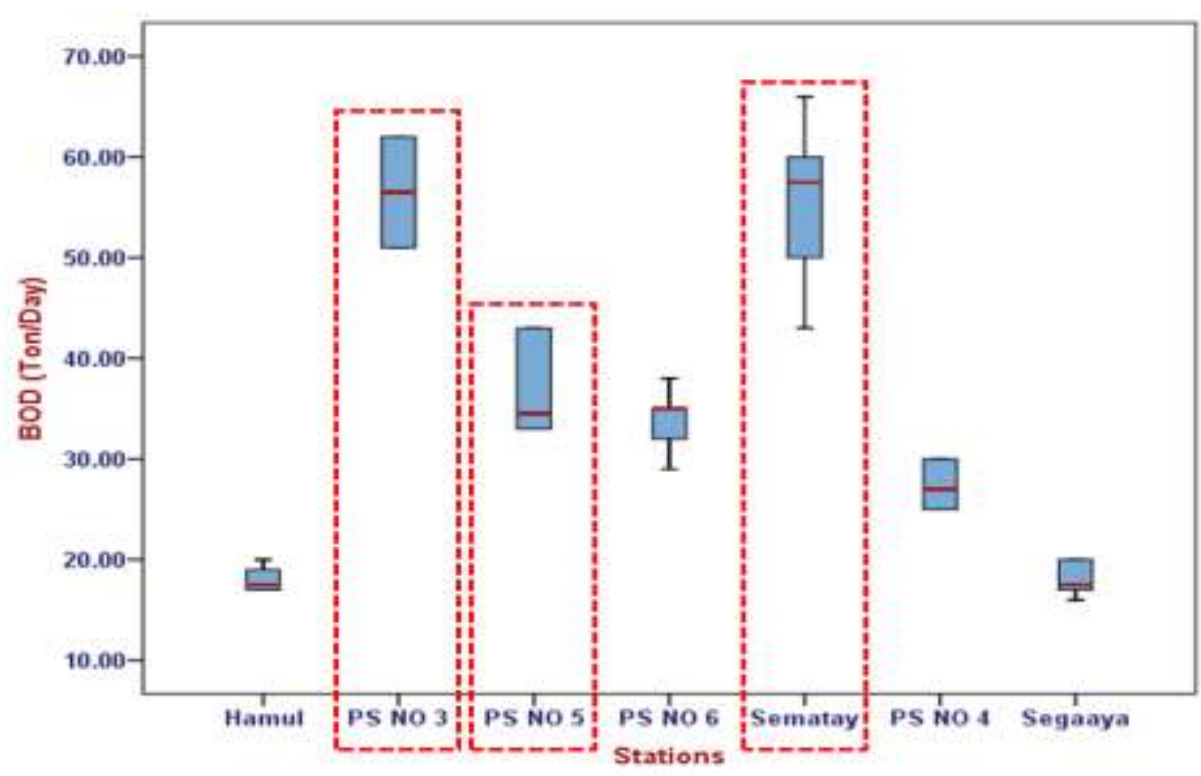

Figure (6): Pollutant load of BOD for all the stations

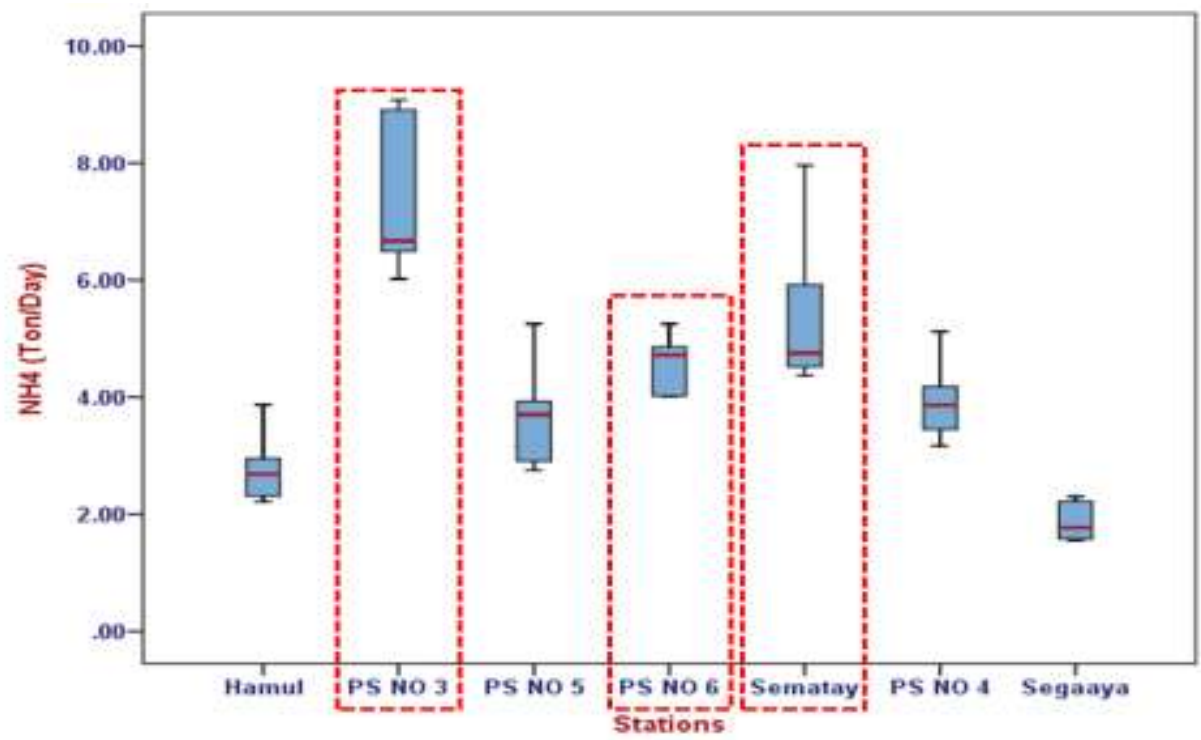

Figure (7): Pollutant load of $\mathrm{NH}_{4}$ for all the stations 


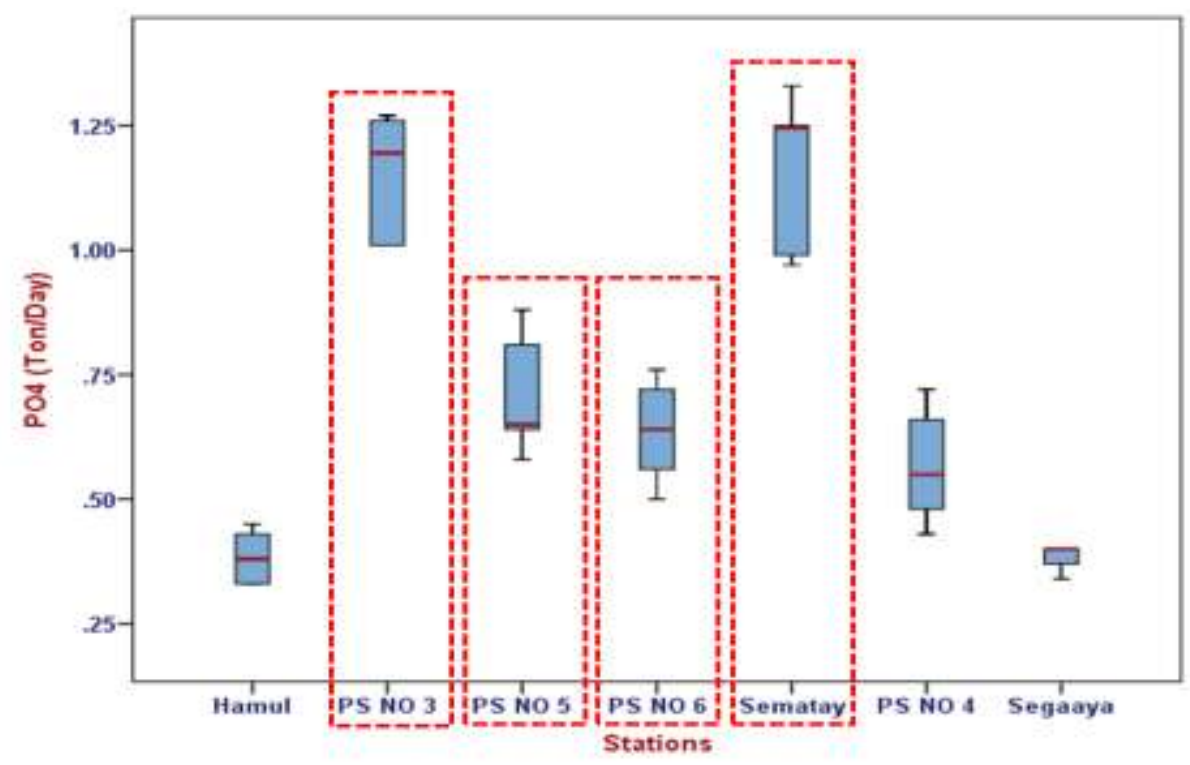

Figure (8): Pollutant load of $\mathrm{PO}_{4}$ for all the stations

Table (2) represent The Water Quality Parameters of Point Sources measured in winter season and have been used to run the model. It is clear that the BOD value ranged from 53.17 to 58.33 . DO ranged from $1.4-2 \mathrm{mg} / \mathrm{l}$ along the drain for example.

Table (2): The Water Quality Parameters of Point Sources

\begin{tabular}{|c|c|c|c|c|c|c|c|c|}
\hline \multirow{2}{*}{ Locations } & \multicolumn{7}{|c|}{ Water Quality Parameter } \\
\cline { 2 - 9 } & DO & BOD & Org N & $\mathbf{N H}_{4}$ & $\mathbf{N O}_{\mathbf{2}}$ & $\mathbf{N O}_{\mathbf{3}}$ & Org P & PO $_{\mathbf{4}}$ \\
\hline Segaaya PS & 1.47 & 53.83 & 6.91 & 5.55 & 0.14 & 11.45 & 2.21 & 1.20 \\
\hline Sematay PS & 1.40 & 55.67 & 5.24 & 5.35 & 0.15 & 15.45 & 2.31 & 1.16 \\
\hline PS NO.5 & 1.65 & 55.83 & 6.42 & 5.67 & 0.13 & 14.97 & 2.28 & 1.08 \\
\hline PS NO.6 & 1.90 & 58.33 & 9.60 & 7.53 & 0.12 & 11.95 & 2.42 & 1.10 \\
\hline Hamul PS & 1.90 & 53.17 & 2.92 & 8.18 & 0.13 & 16.33 & 2.13 & 1.12 \\
\hline PS NO.4,3 & 2.00 & 55.00 & 6.18 & 7.51 & 0.12 & 14.69 & 2.32 & 1.13 \\
\hline
\end{tabular}


Water Quality Assessment: Table (3) represent the observed and simulated water quality parameters with respect to (Segaaya and Sematay mixed), Ezbet El Nile Bridge and Gharbia Main Drain (Km 46.40) showed very low variation in most water quality parameters between the measured and simulated values. So that it was clear that the model was adequate to fit water quality simulation.

Table (3): The observed and simulated water quality parameters

\begin{tabular}{|c|c|c|c|c|c|c|c|c|c|}
\hline \multirow{2}{*}{ Location } & & \multicolumn{8}{|c|}{ Water Quality Parameter } \\
\hline & & DO & BOD & $\mathrm{NH}_{4}$ & $\mathrm{NO}_{3}$ & $\mathrm{NO}_{2}$ & Org N & $\mathbf{P O}_{4}$ & Org $P$ \\
\hline \multirow{3}{*}{$\begin{array}{l}\text { Segaaya } \\
\text { and } \\
\text { Sematay } \\
\text { mixed } \\
(\mathrm{Km} 54.6)\end{array}$} & Observed & 1.80 & 54.5 & 5.36 & 15 & 0.18 & 5.40 & 1.17 & 2.28 \\
\hline & $\begin{array}{c}\text { Simulated } \\
\text { After }\end{array}$ & \multirow{2}{*}{1.60} & \multirow{2}{*}{55.38} & \multirow{2}{*}{4.32} & \multirow{2}{*}{13.95} & \multirow{2}{*}{0.14} & \multirow{2}{*}{4.40} & \multirow{2}{*}{1.60} & \multirow{2}{*}{3.40} \\
\hline & $\begin{array}{c}\text { Model } \\
\text { Calibration }\end{array}$ & & & & & & & & \\
\hline \multirow{3}{*}{$\begin{array}{c}\text { Gharbia } \\
\text { Main } \\
\text { Drain } \\
\text { (Km 46.4) }\end{array}$} & Observed & 2.11 & 55 & 5.43 & 15 & 0.2 & 5.70 & 1.15 & 2.28 \\
\hline & $\begin{array}{c}\text { Simulated } \\
\text { After }\end{array}$ & \multirow{2}{*}{2.00} & \multirow{2}{*}{56.43} & \multirow{2}{*}{4.45} & \multirow{2}{*}{13.20} & \multirow{2}{*}{0.13} & \multirow{2}{*}{4.71} & \multirow{2}{*}{1.50} & \multirow{2}{*}{3.20} \\
\hline & $\begin{array}{c}\text { Model } \\
\text { Calibration }\end{array}$ & & & & & & & & \\
\hline \multirow{3}{*}{$\begin{array}{l}\text { Ezbet El } \\
\text { Nile } \\
\text { Bridge } \\
\text { (Km 38.6) }\end{array}$} & Observed & 2.40 & 56 & 5.4 & 14.9 & 0.26 & 5.68 & 1.15 & 2.27 \\
\hline & $\begin{array}{c}\text { Simulated } \\
\text { After }\end{array}$ & \multirow{2}{*}{2.01} & \multirow{2}{*}{57.43} & \multirow{2}{*}{4.60} & \multirow{2}{*}{13.40} & \multirow{2}{*}{0.10} & \multirow{2}{*}{4.50} & \multirow{2}{*}{1.30} & \multirow{2}{*}{3.50} \\
\hline & $\begin{array}{c}\text { Model } \\
\text { Calibration }\end{array}$ & & & & & & & & \\
\hline
\end{tabular}

The mean squared error was calculated and it is clear that the lowest error recorded in $\mathrm{NH}_{4}$ concentrations for Segaaya and Sematay mixed, $\mathrm{NO}_{3}$ concentrations for Ezbet El Nile Bridge but the highest error ratio was 
recorded for DO concentrations for Segaaya and Sematay mixed and Ezbet El Nile Bridge as shown in table (4).

Table (4): The mean squared error

\begin{tabular}{||c|c|c|c|c|c|c|c|c|}
\hline & \multicolumn{7}{|c|}{ Mean Squared Error } \\
\hline & DO & BOD & $\mathbf{N H}_{4}$ & $\mathbf{N O}_{\mathbf{3}}$ & $\mathbf{N O}_{\mathbf{2}}$ & OrgN & $\mathbf{P O}_{\mathbf{4}}$ & OrgP \\
\hline \hline $\begin{array}{c}\text { Segaaya and } \\
\text { Sematay } \\
\text { mixed }\end{array}$ & 0.00371 & 0.02455 & 0.00339 & 0.14165 & 0.000 & 0.00005 & 0.000 & 0.010 \\
\hline $\begin{array}{c}\text { Gharbia } \\
\text { Main Drain } \\
\text { (Km 46.4) }\end{array}$ & 0.01580 & 0.05593 & 0.00604 & 0.1410 & 0.000 & 0.00886 & 0.010 & 0.010 \\
\hline $\begin{array}{c}\text { Ezbet El Nile } \\
\text { Bridge }\end{array}$ & 0.00425 & 0.00609 & 0.01859 & 0.000 & 0.000 & 0.01016 & 0.010 & 0.000 \\
\hline
\end{tabular}

Where, the mean squared error represents the closeness of a regression line to a set of points by taking the distances from the points to the regression line (i.e. these distances are the "errors") and squaring them. The squaring is necessary to remove any negative signs.

Table (5) represents the meteorological data of point sources that have been used as the required input data model for both winter and summer season. These results were collected from the metrological stations along the drain. 
Table (5): Meteorological Data of Point Sources

\begin{tabular}{|c|c|c|c|c|c|c|c|}
\hline & & $\begin{array}{c}\text { Atmospheric } \\
\text { pressure } \\
(\mathrm{mb})\end{array}$ & $\begin{array}{c}\text { Air } \\
\text { Temp } \\
.\left({ }^{\circ} \mathrm{C}\right)\end{array}$ & $\begin{array}{c}\text { Humidity } \\
(\%)\end{array}$ & $\begin{array}{c}\text { Solar Radiation } \\
\text { (Short Wave } \\
\text { Radiation) W/m2 }\end{array}$ & $\begin{array}{c}\text { Cloudiness } \\
(\%)\end{array}$ & $\begin{array}{l}\text { Wind } \\
\text { Speed } \\
(\text { mph })\end{array}$ \\
\hline $\begin{array}{l}\text { Segaaya } \\
\text { PS }\end{array}$ & \multirow{5}{*}{ : } & 1022 & 16.2 & 71 & 86.67 & 48 & 4 \\
\hline $\begin{array}{c}\text { Sematay } \\
\text { PS }\end{array}$ & & 1022 & 16.2 & 71 & 86.67 & 48 & 4 \\
\hline PS NO.5 & & 1022 & 16.3 & 69 & 86.67 & 62 & 4 \\
\hline PS NO.6 & & 1022 & 16.5 & 66 & 86.67 & 59 & 6 \\
\hline $\begin{array}{c}\text { PS } \\
\text { NO.4,3 }\end{array}$ & & 1023 & 15.8 & 58 & 86.67 & 57 & 5 \\
\hline $\begin{array}{l}\text { Segaaya } \\
\text { PS }\end{array}$ & \multirow{5}{*}{ 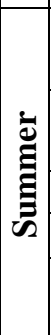 } & 1011 & 38.2 & 50 & 268.61 & 21 & 4 \\
\hline $\begin{array}{l}\text { Sematay } \\
\text { PS }\end{array}$ & & 1011 & 38.2 & 50 & 268.61 & 21 & 4 \\
\hline PS NO.5 & & 1011 & 37.2 & 54 & 268.61 & 23 & 4 \\
\hline PS NO.6 & & 1011 & 35.7 & 57 & 268.61 & 16 & 4 \\
\hline $\begin{array}{c}\text { PS } \\
\text { NO.4,3 }\end{array}$ & & 1011 & 36.7 & 52 & 268.61 & 14 & 5 \\
\hline
\end{tabular}

In order to use the water quality model for the scenario input prediction, a calibration is done comparing the model output with the measured data for the year (2015/2016). The criteria with respect to the required accuracy of the simulation have been determined and the procedure for calibration continued until the error of the network reduced to the acceptable level as shown in figure $(9,10,11,12$ and 13). 
J. Environ. Sci.

Institute of Environmental Studies and Research - Ain Shams University

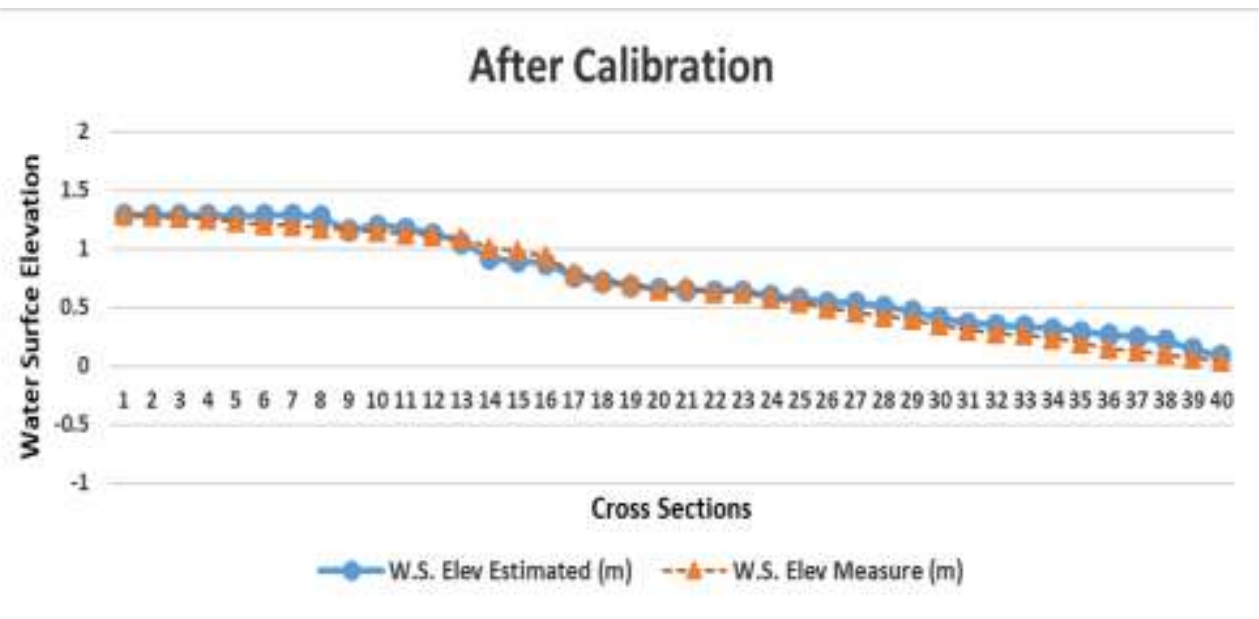

Figure (9): The Model Result for water surface elevation after Calibration

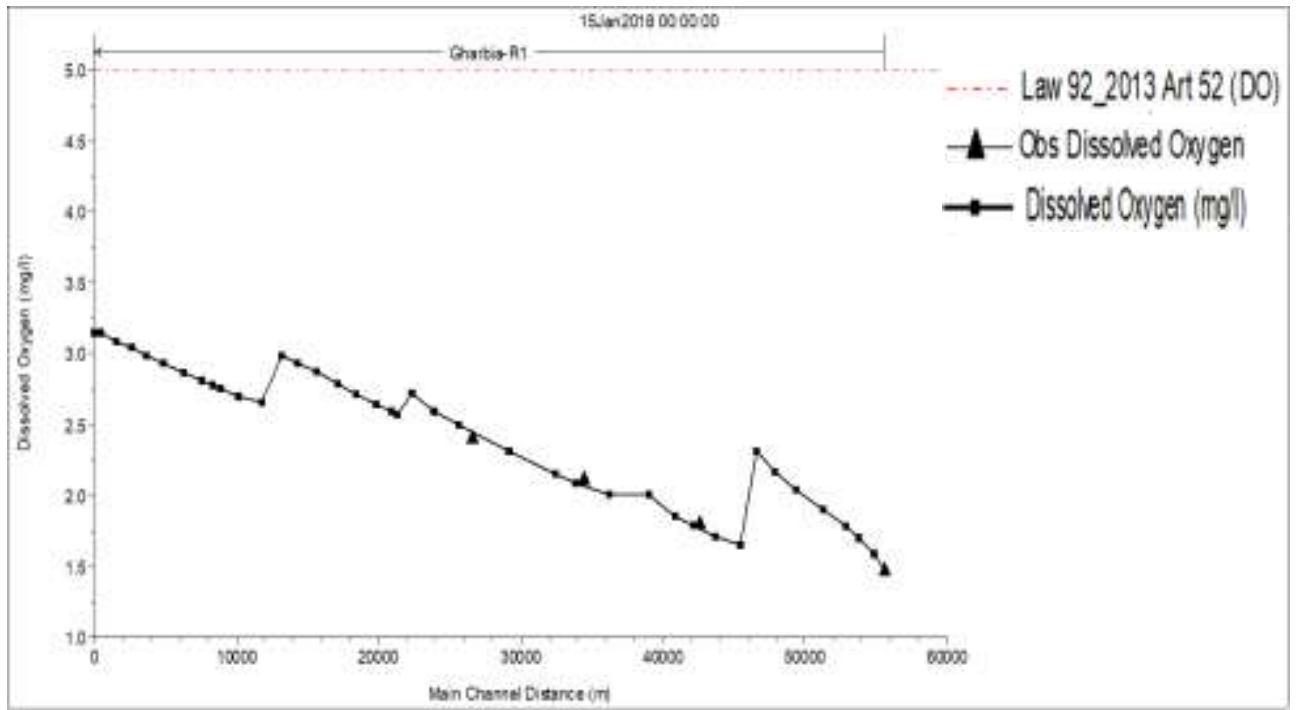

Figure (10): The Model Result for DO after Calibration 


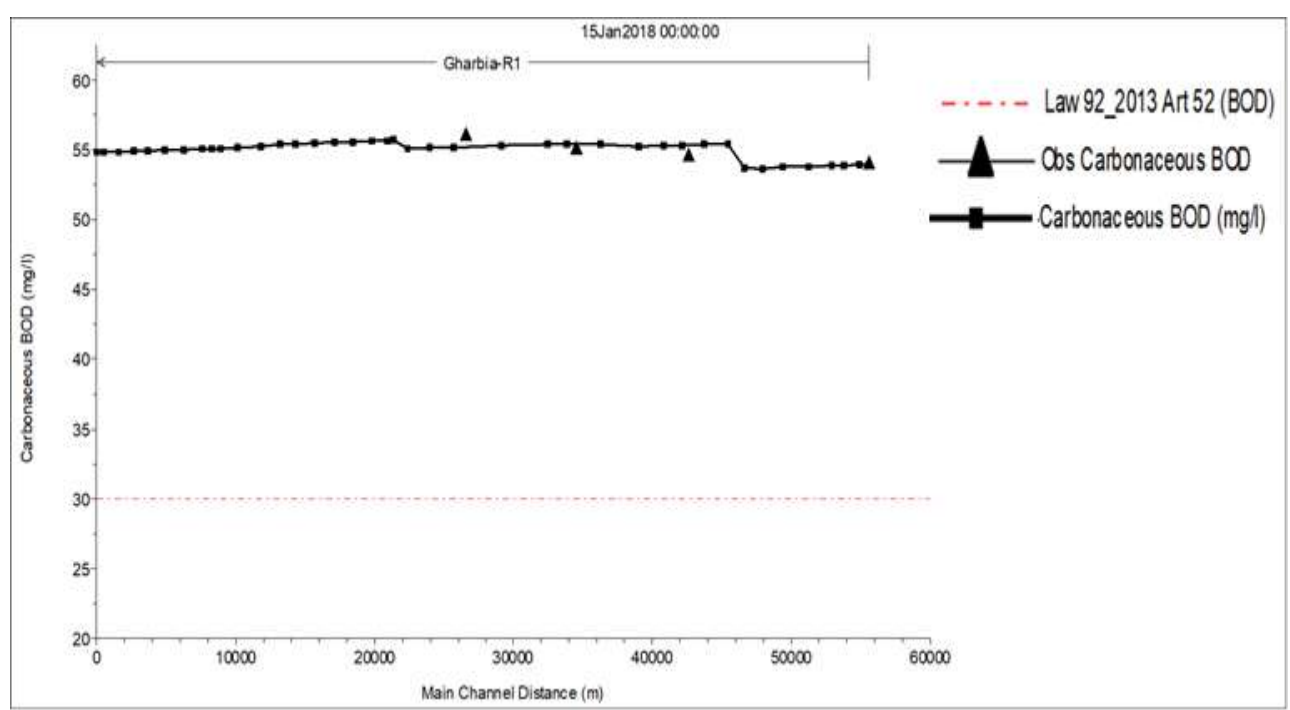

Figure (11): The Model Result for BOD after Calibration

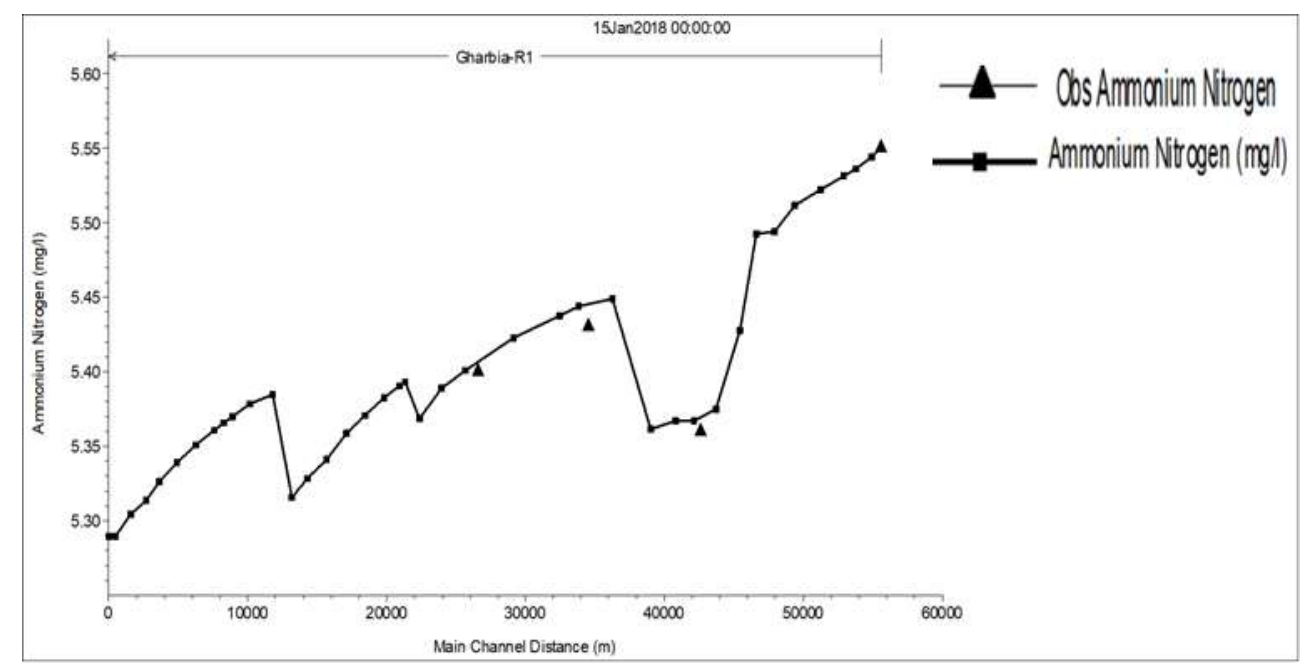

Figure (12): The Model Result for $\mathrm{NH}_{4}$ after Calibration 
J. Environ. Sci.

Institute of Environmental Studies and Research - Ain Shams University

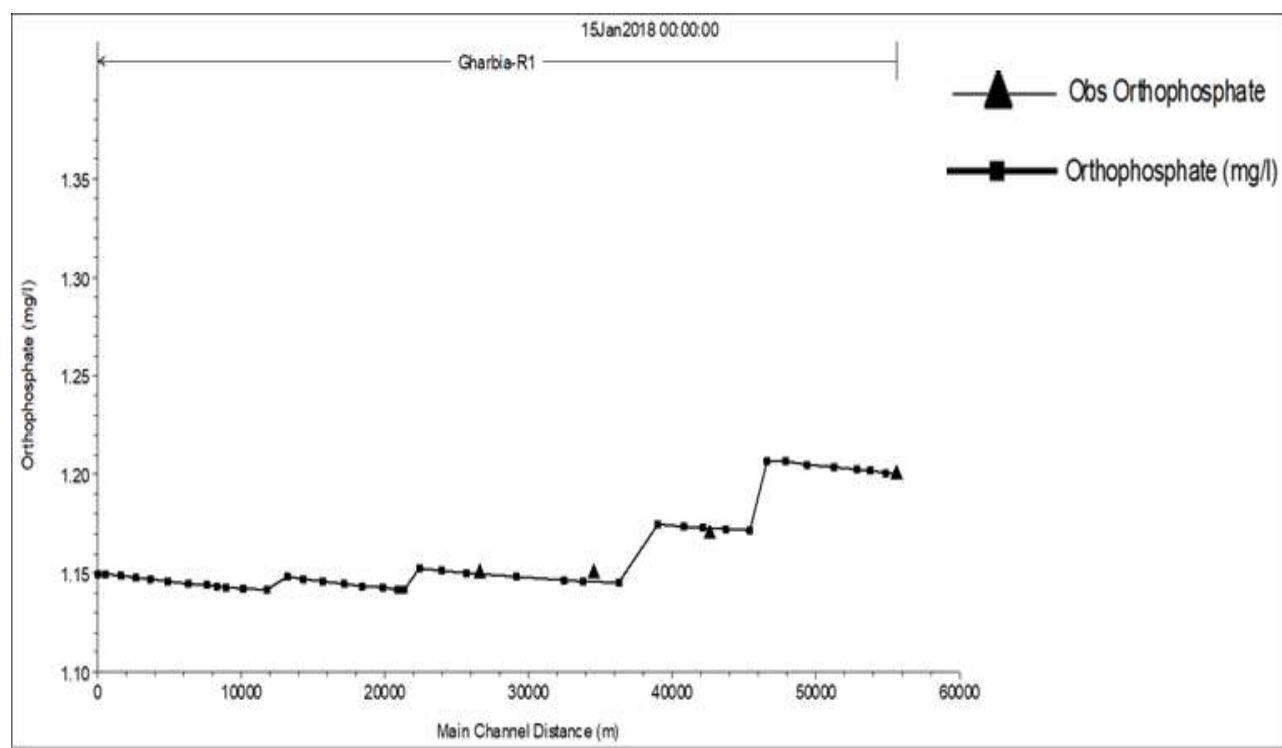

Figure (13): The Model Result for $\mathrm{PO}_{4}$ after Calibration

The validation of the calibrated model is done by using a different set of data (2015/2016) as shown in figures (14, 15, 16, and 17).

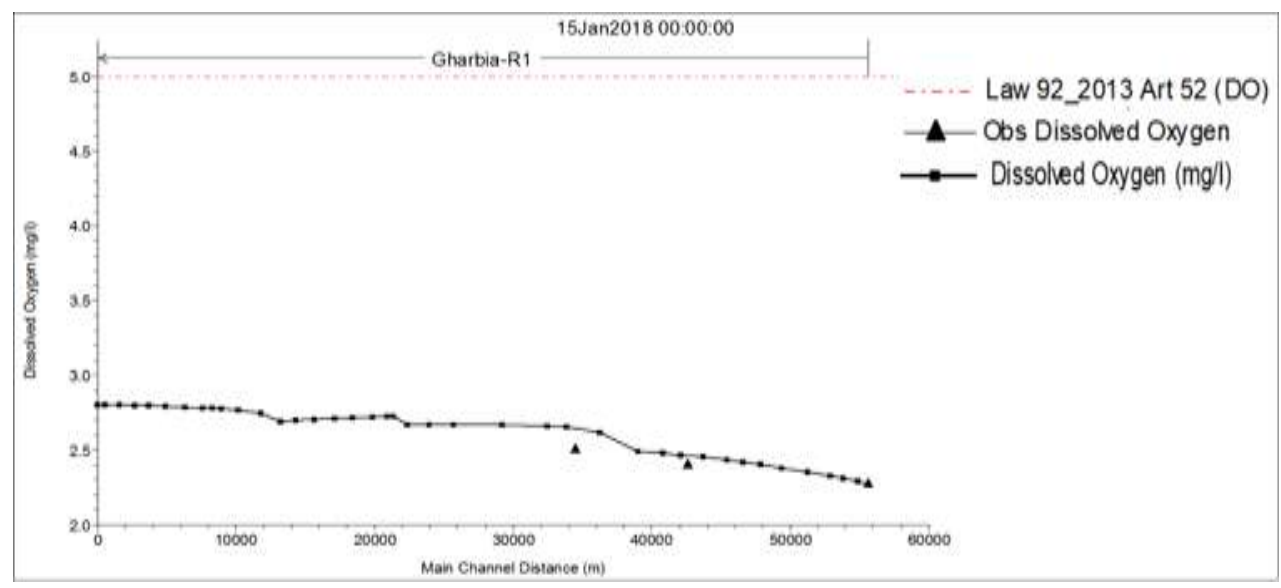

Figure (14): The Model Result for DO after Verification 
El-Sherbiny et al.

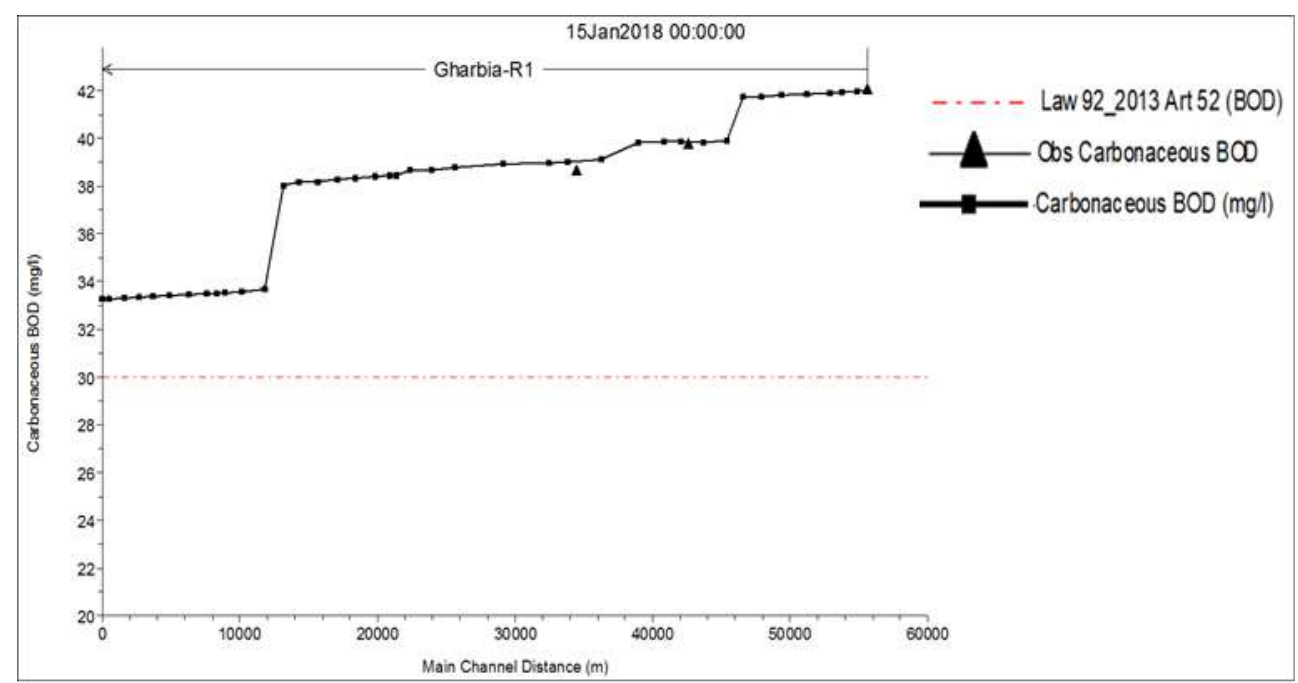

Figure (15): The Model Result for BOD after Verification

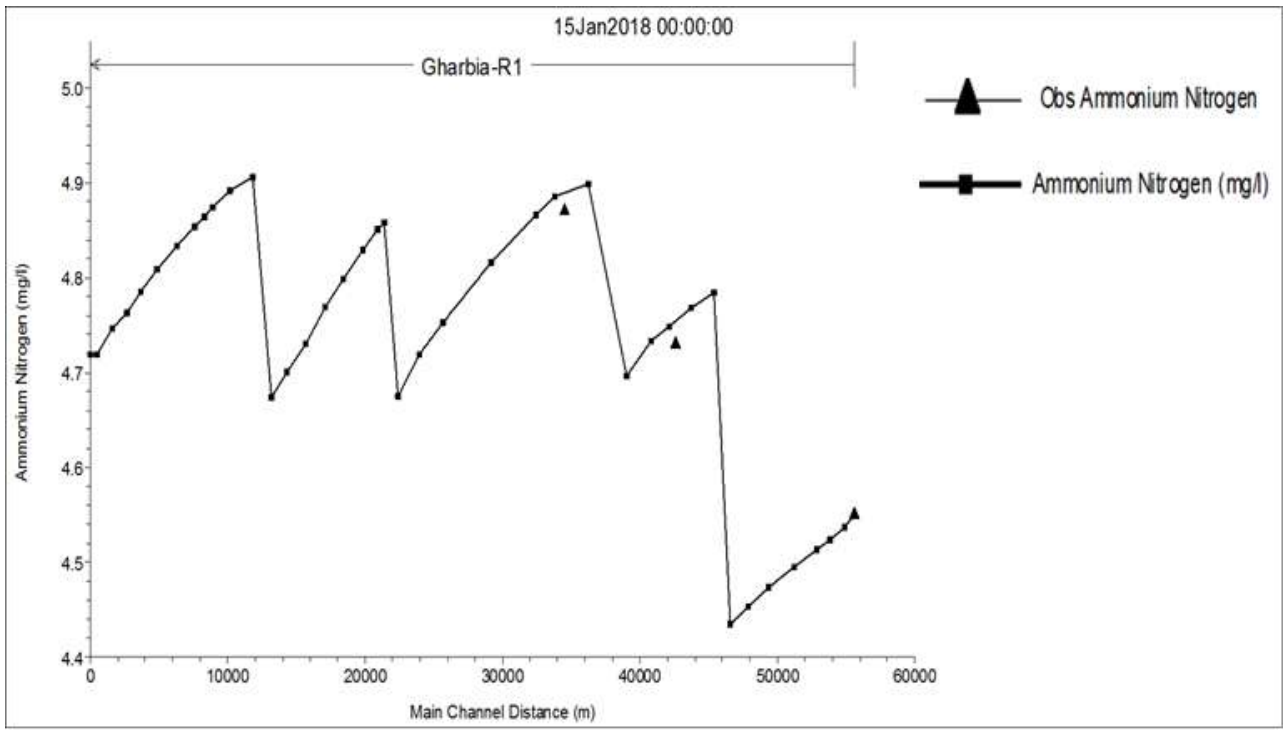

Figure (16): The Model Result for $\mathrm{NH}_{4}$ after Verification 
J. Environ. Sci.

Institute of Environmental Studies and Research - Ain Shams University

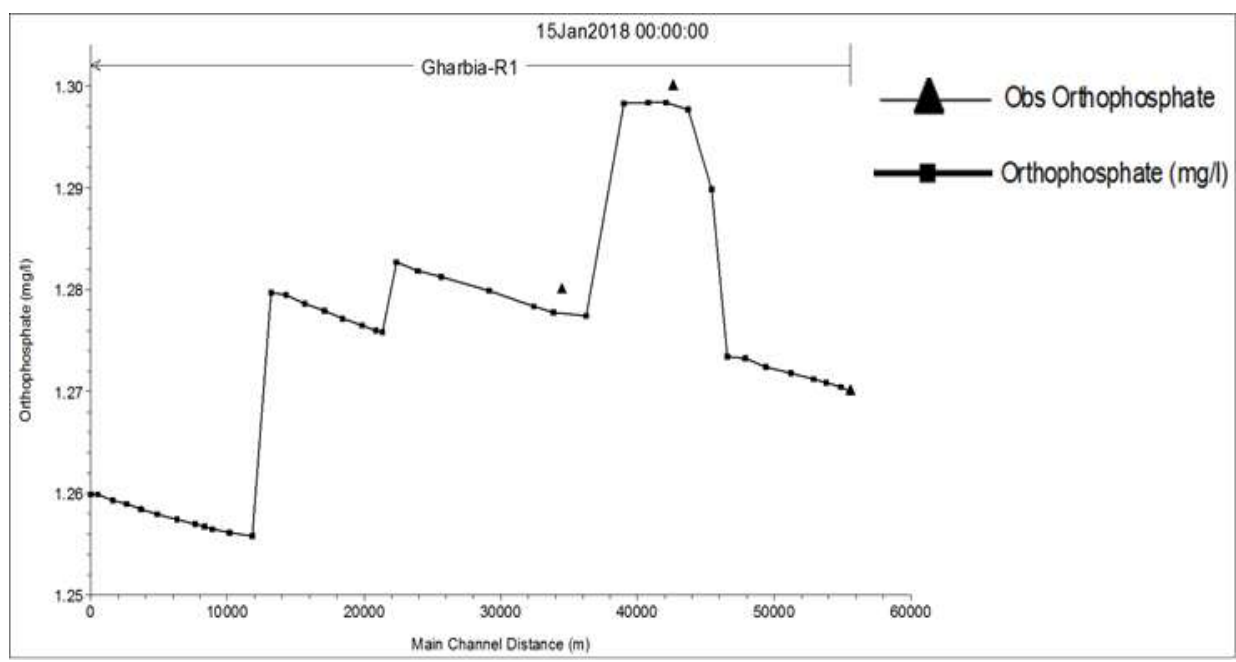

Figure (17): The Model Result for $\mathrm{PO}_{4}$ after Verification

The model results output represented the velocity, water surface profile and total discharge along the main drain as shown in the figures $(18,19$ and 20).

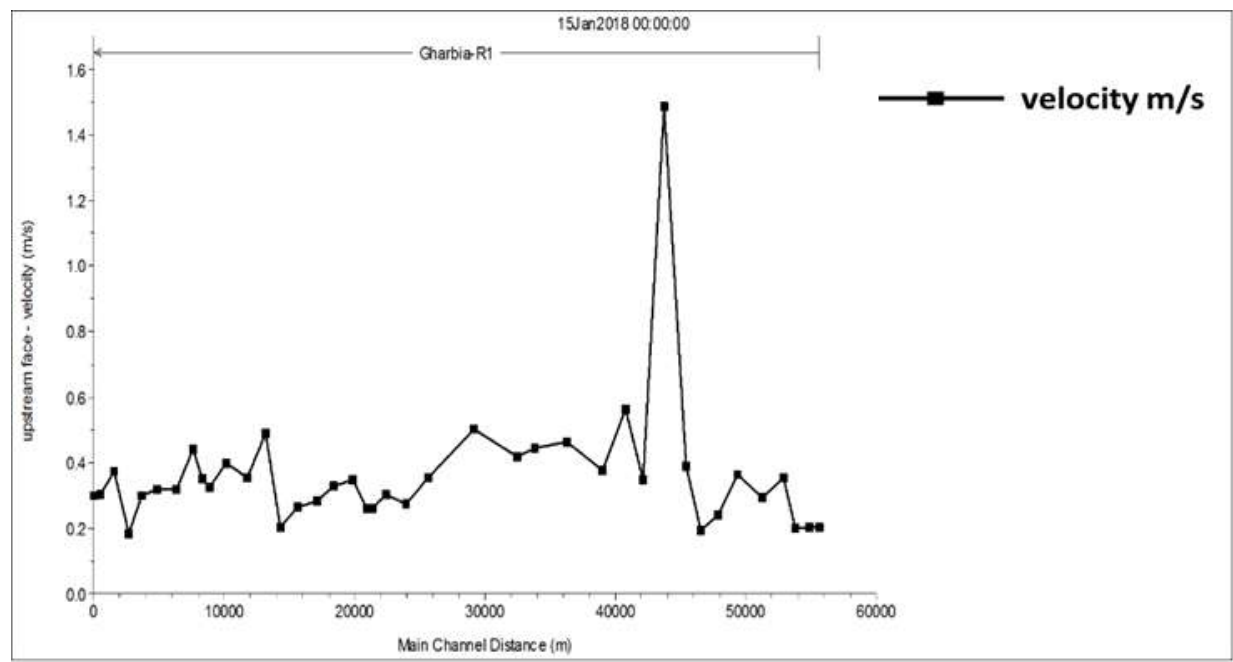

Figure (18): The Velocity along the main Drain 


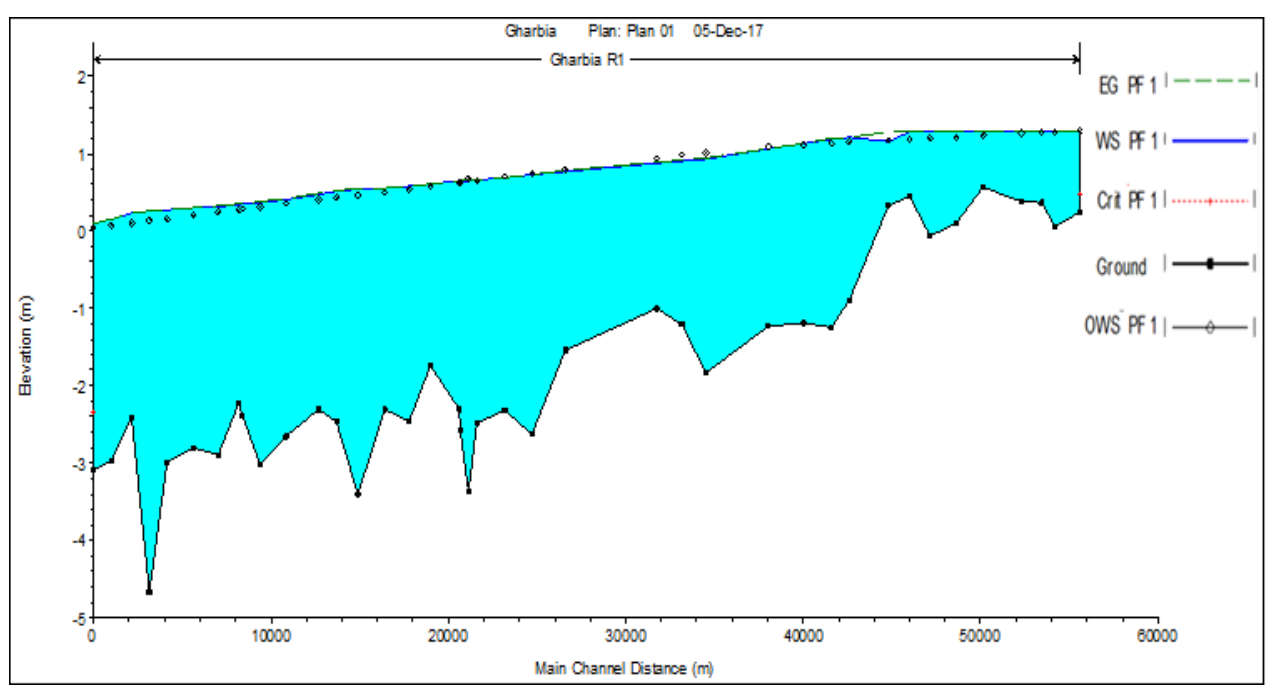

Figure (19): Water Surface Profile along the main drain

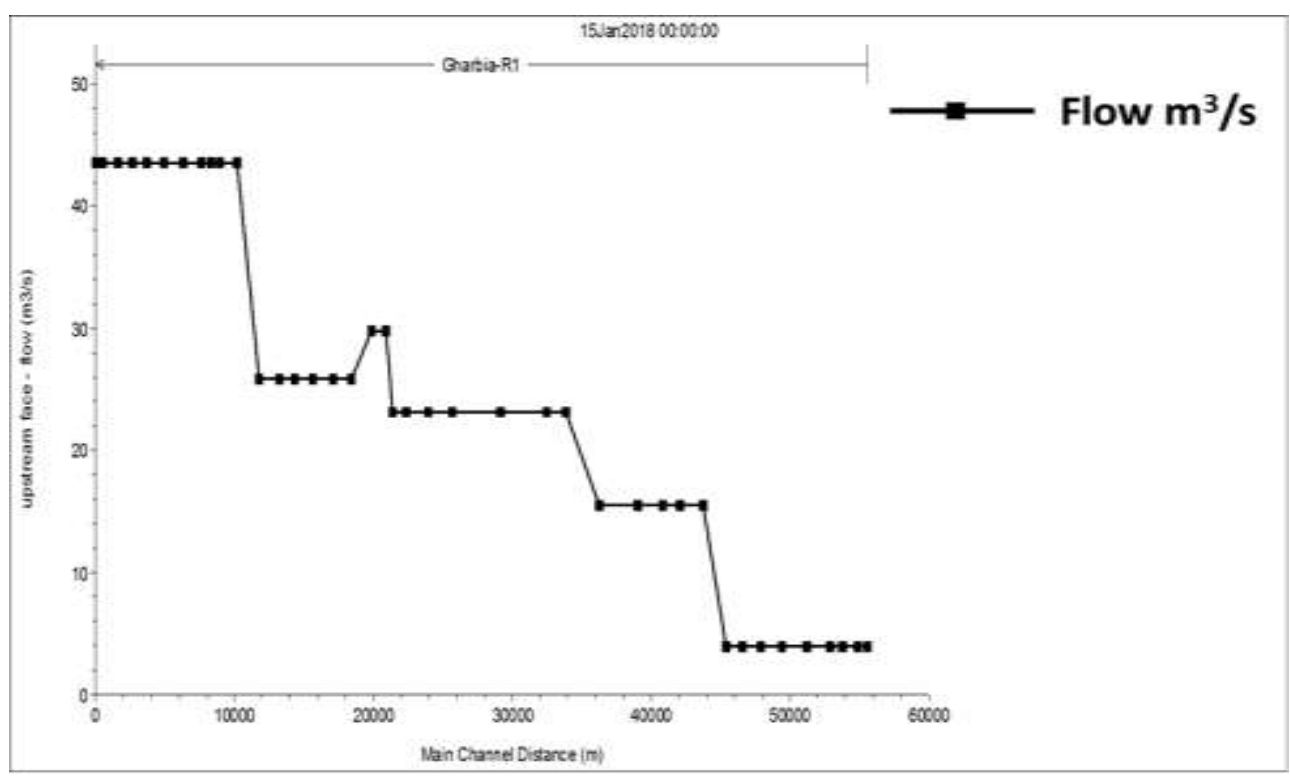

Figure (20): Total Discharge along the main drain 
According to figure (18) the velocity, at $\mathrm{Km} 67.5$ at the beginning of the drain, was $0.2 \mathrm{~m} / \mathrm{s}$ and reached to $0.3 \mathrm{~m} / \mathrm{s}$ at $\mathrm{km} 12$ at the end of the drain.

The highest value was recorded at $\mathrm{km} 56.8$ and it was $1.49 \mathrm{~m} / \mathrm{sec}$ where the lowest value was at $\mathrm{km} 15.1$ and it was $0.18 \mathrm{~m} / \mathrm{s}$.

Figure (19): The water depth at $\mathrm{Km} 67.5$ at the beginning of the drain was $0.24 \mathrm{~m}$ and reached to 3.08 at $\mathrm{km} 12$ at the end of the drain. The highest water depth at km15 was $-4.66 \mathrm{~m}$ along the drain.

Figure (20): the discharge at $\mathrm{Km} 67.5$ at the beginning of the drain was $3.59 \mathrm{~m}^{3} / \mathrm{s}$ and reached to $43.52 \mathrm{~m}^{3} / \mathrm{s}$ at $\mathrm{km} 12$ at the end of the drain. The discharge has been increased at $\mathrm{km} 58$ to $15.52 \mathrm{~m}^{3} / \mathrm{s}$ due to the drain of Samatay P.S. to the drain. The discharge also increased at $\mathrm{km} 46.4$ to 23.1 $\mathrm{m}^{3} / \mathrm{s}$ due to the drain of Pump stations (5) to the drain.

The discharge increased at $\mathrm{km} 33.1$ to $29.8 \mathrm{~m}^{3} / \mathrm{s}$ due to the drain of Pump stations (6) to the drain. And the discharge decreased at $\mathrm{km} 32.6$ to $25.9 \mathrm{~m}^{3} / \mathrm{s}$ due to El-Hamol uptake from the drain, the discharge increased at the end of the drain at $\mathrm{km} 12$ and reached to 543.52 due to the drain of Pump stations (3, $4)$.

Model Scenarios and Interventions: The six water quality scenarios are presented in figures $(21,22,23,24,25,26,27$ and 28). 


\section{DO Scenarios $25 \%$}

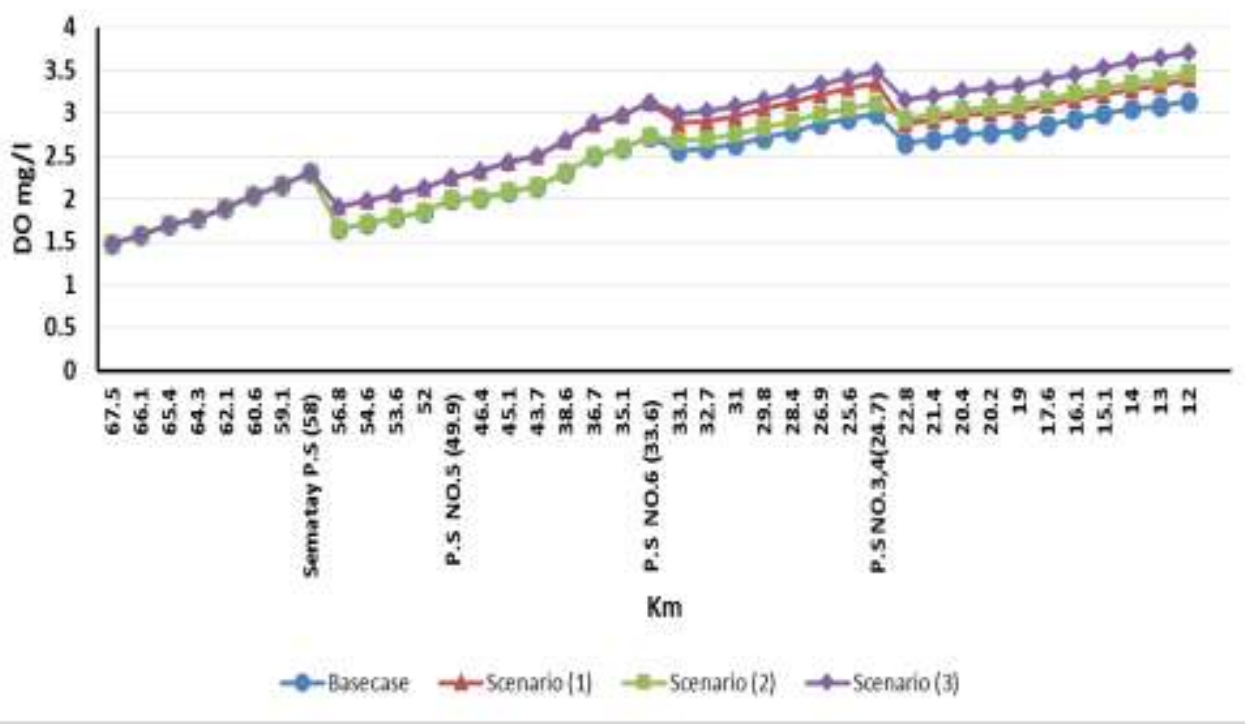

Figure (21): Dissolved Oxygen Scenarios (25\%)

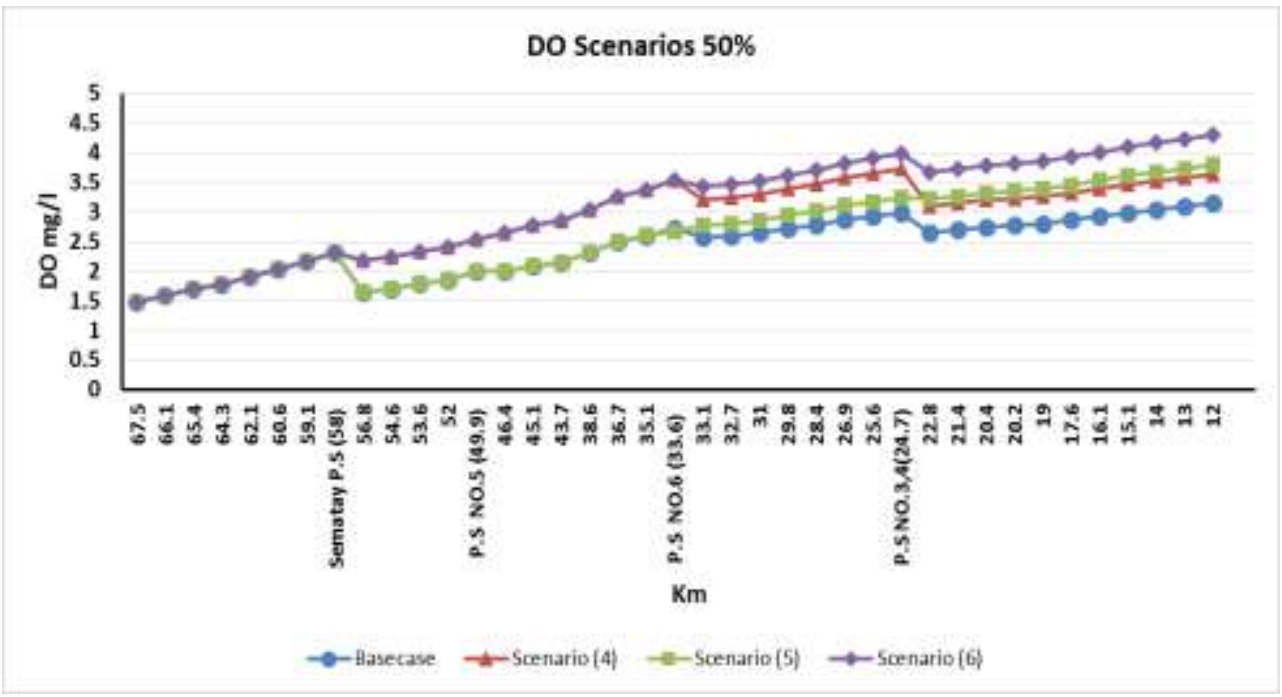

Figure (22): Dissolved Oxygen Scenarios (50\%) 
J. Environ. Sci.

Institute of Environmental Studies and Research - Ain Shams University

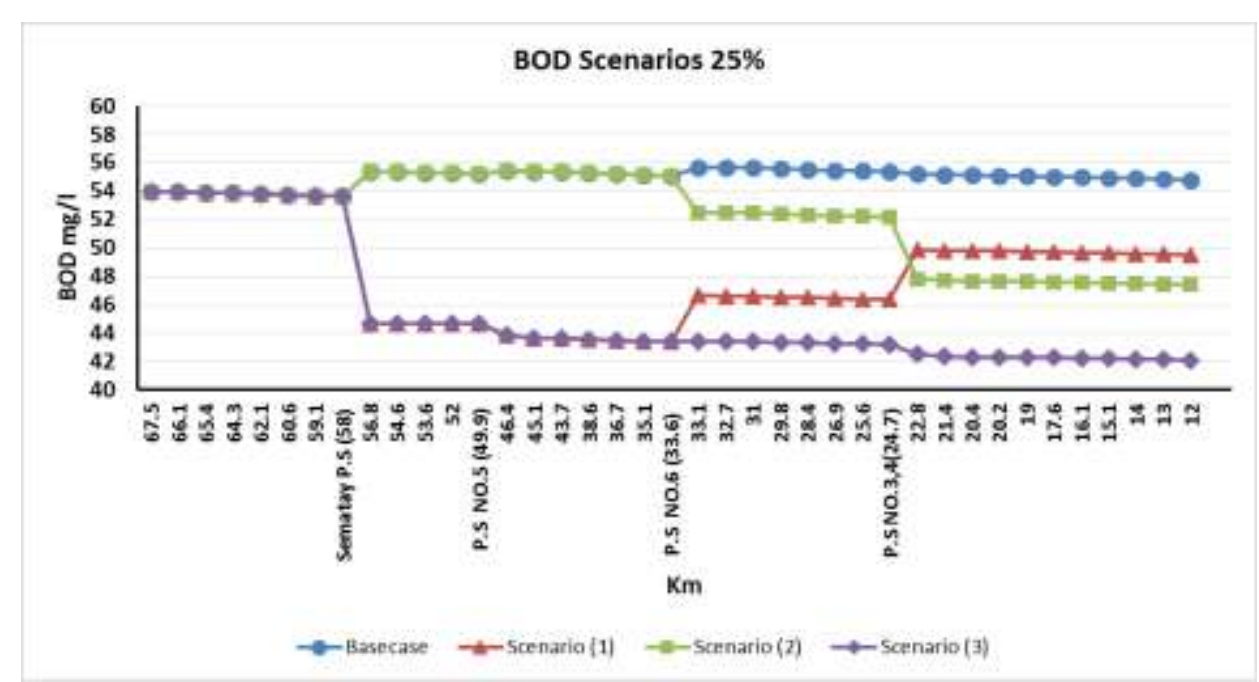

Figure (23): BOD Scenarios (25\%)

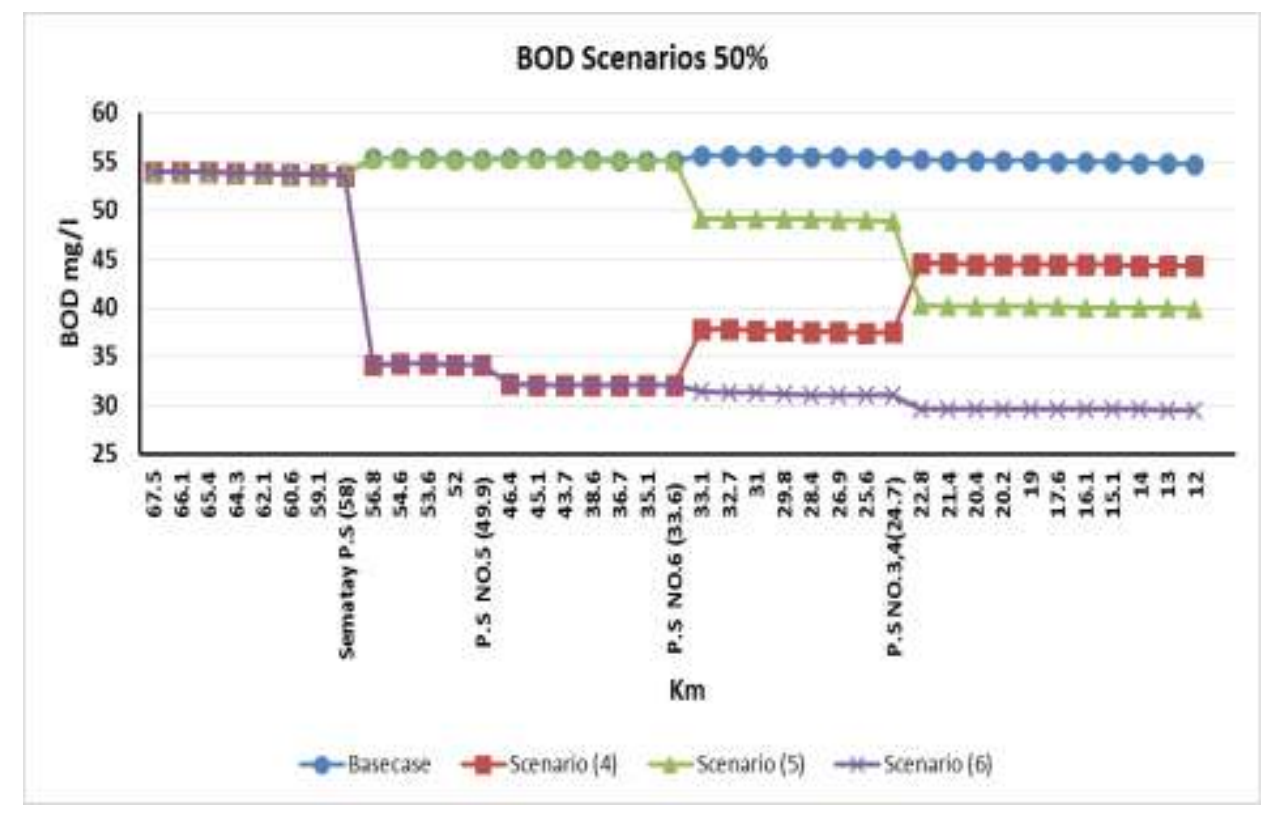

Figure (24): BOD Scenarios (50\%) 


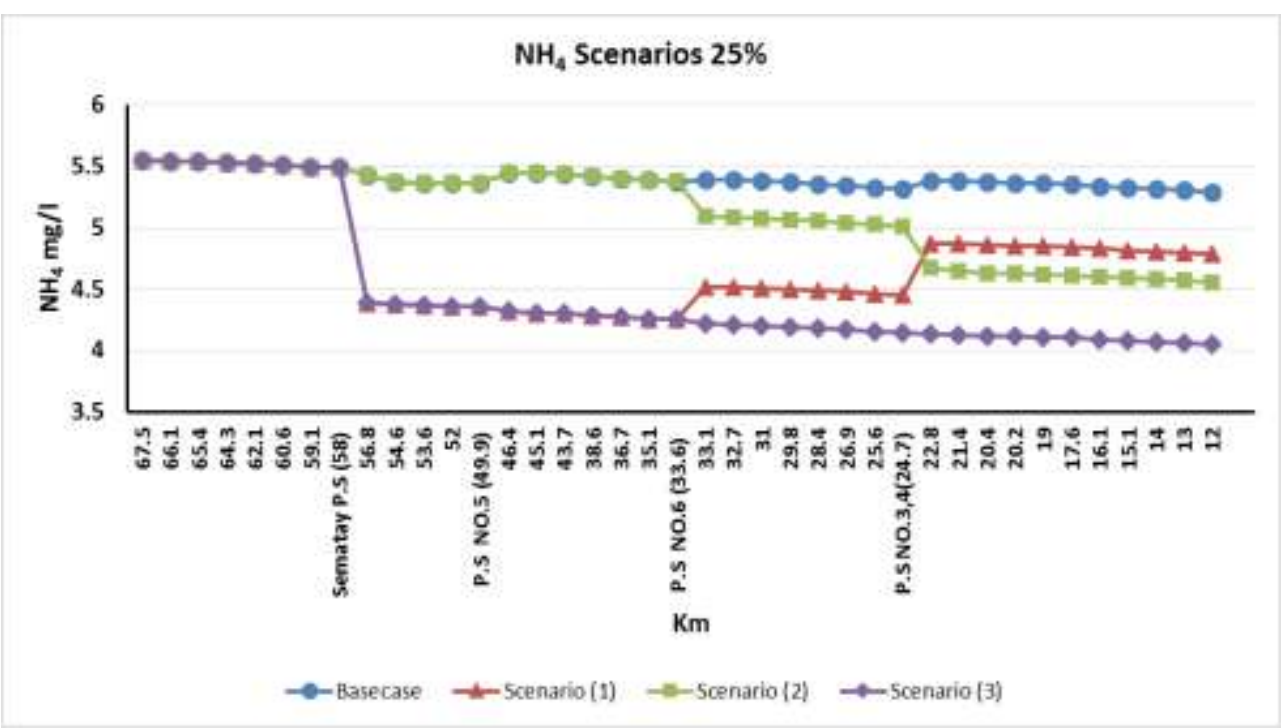

Figure (25): NH4 Scenarios (25\%)

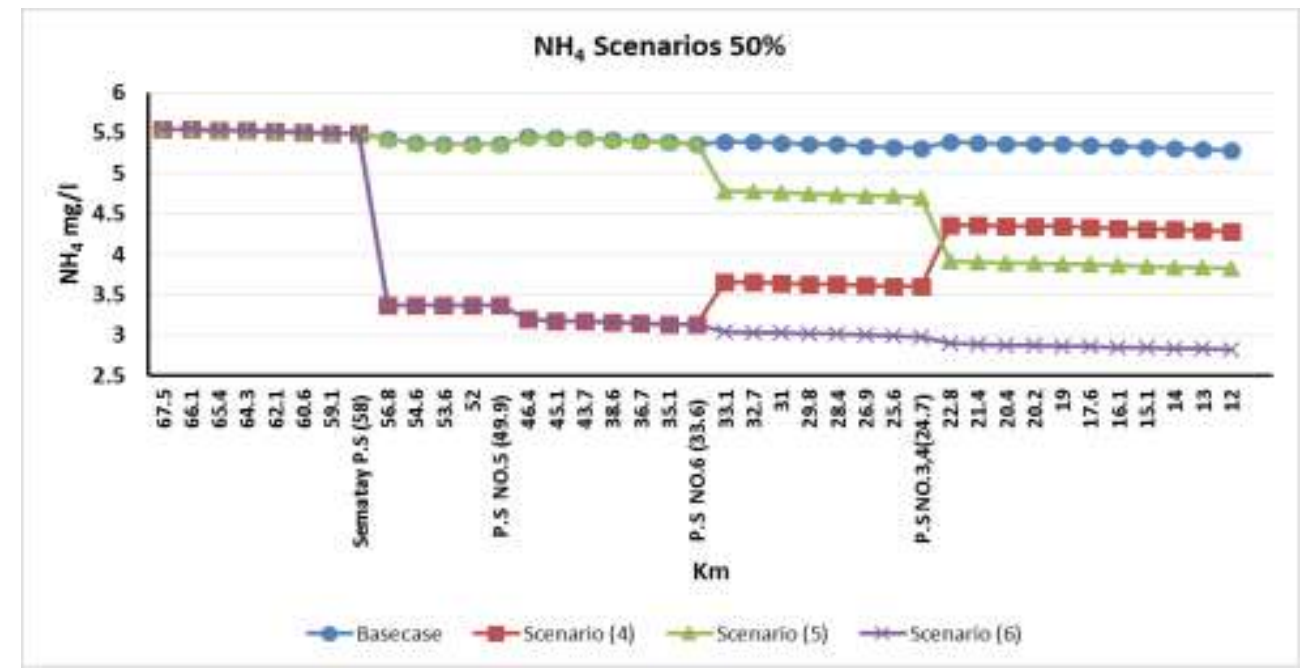

Figure (26): NH4 Scenarios (50\%) 
J. Environ. Sci.

Institute of Environmental Studies and Research - Ain Shams University

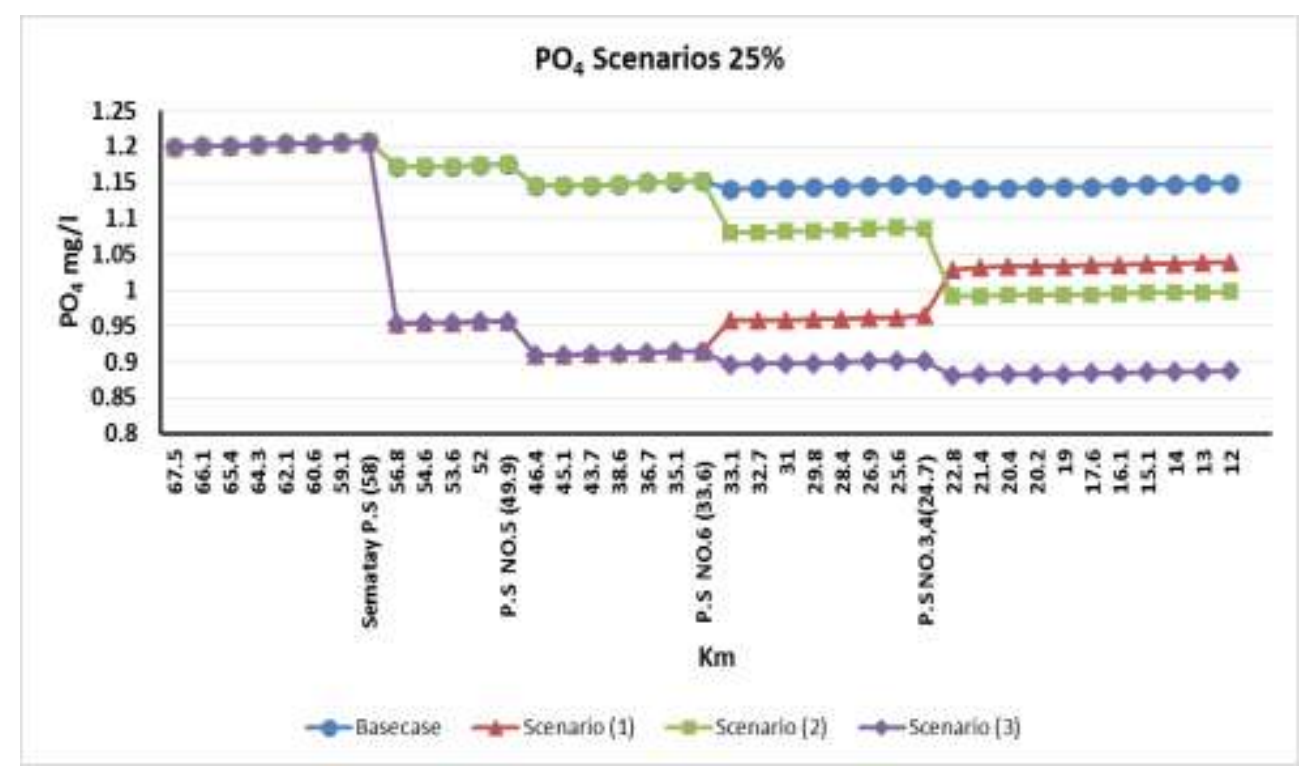

Figure (27): Ortho-Phosphate Scenarios (25\%)

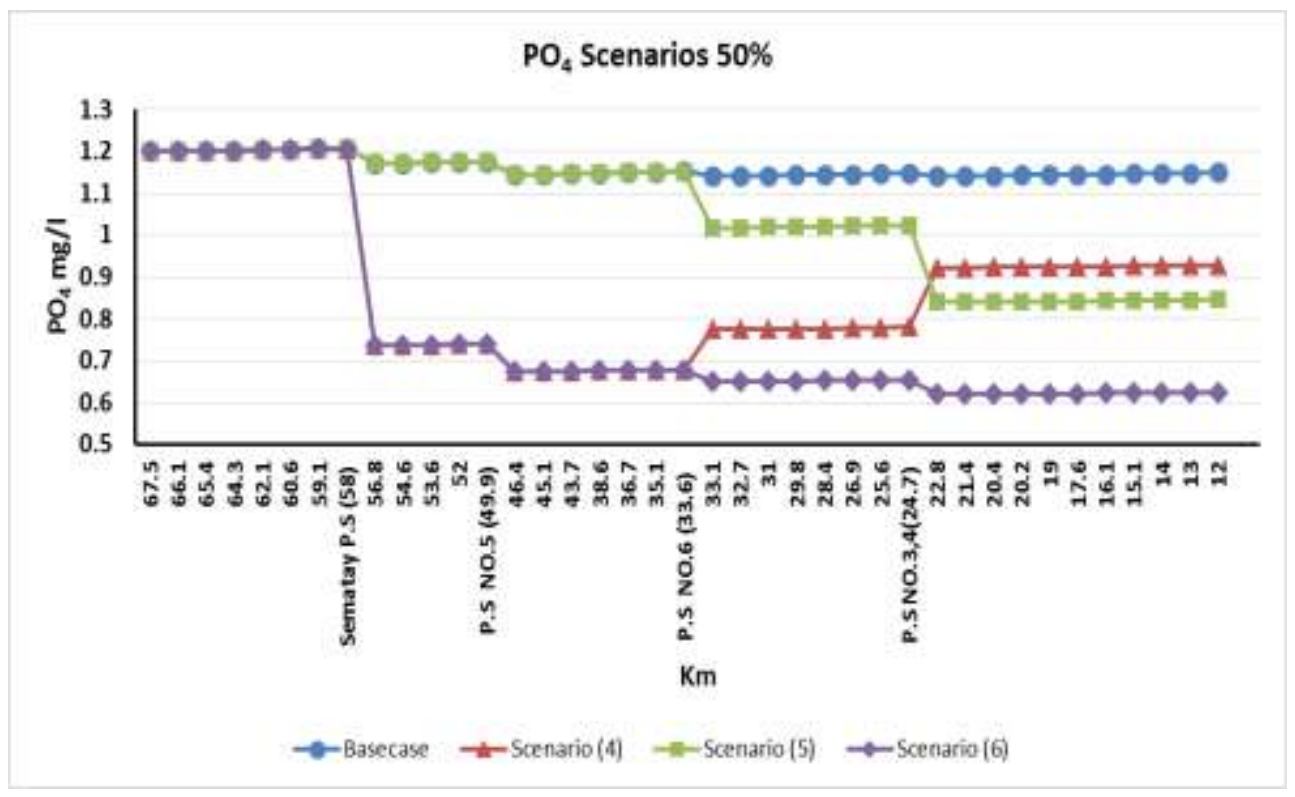

Figure (28): Ortho-Phosphate Scenarios (50\%) 
And the improvement ratios in different water quality parameters are presented in figures $(29,30,31$ and 32$)$.

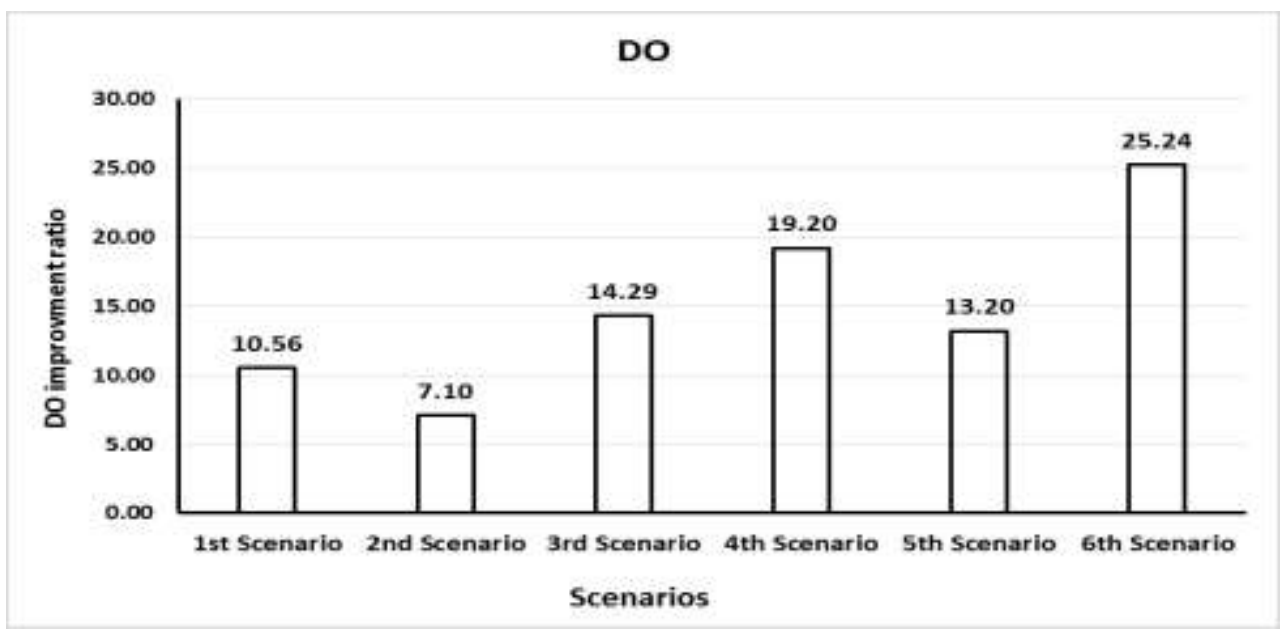

Figure (29): Improvement Ratio of DO for the six Scenarios

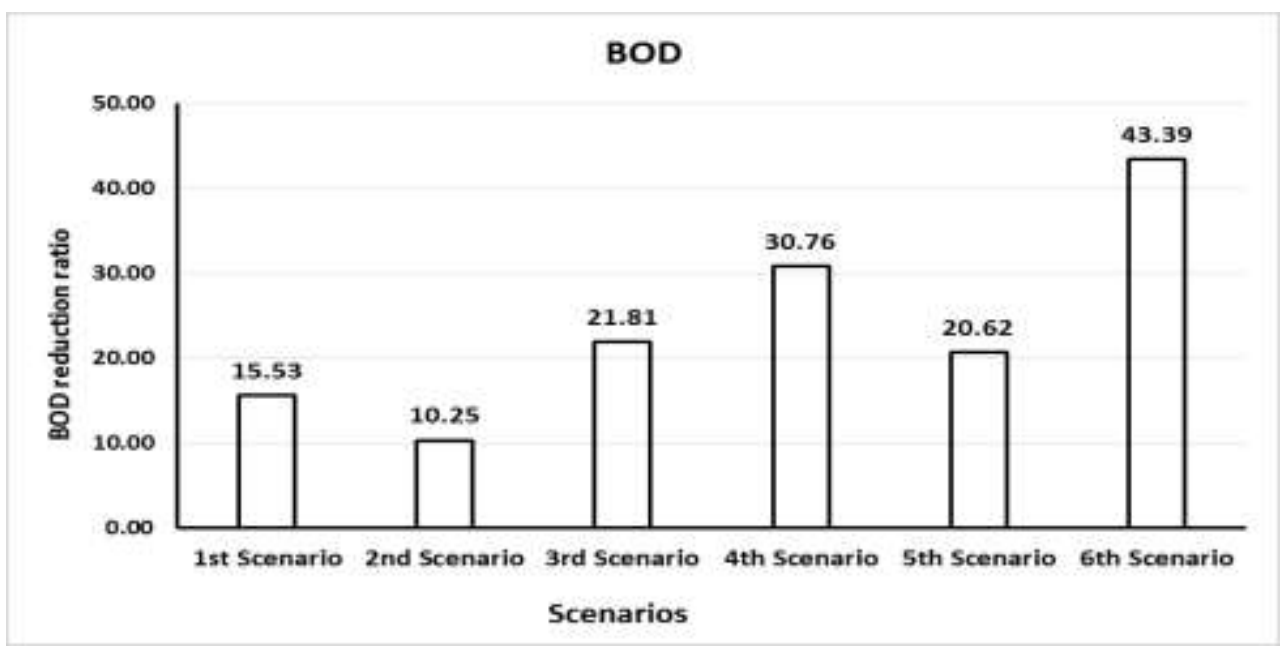

Figure (30): Improvement Ratio of BOD for the six Scenarios 
J. Environ. Sci.

Institute of Environmental Studies and Research - Ain Shams University

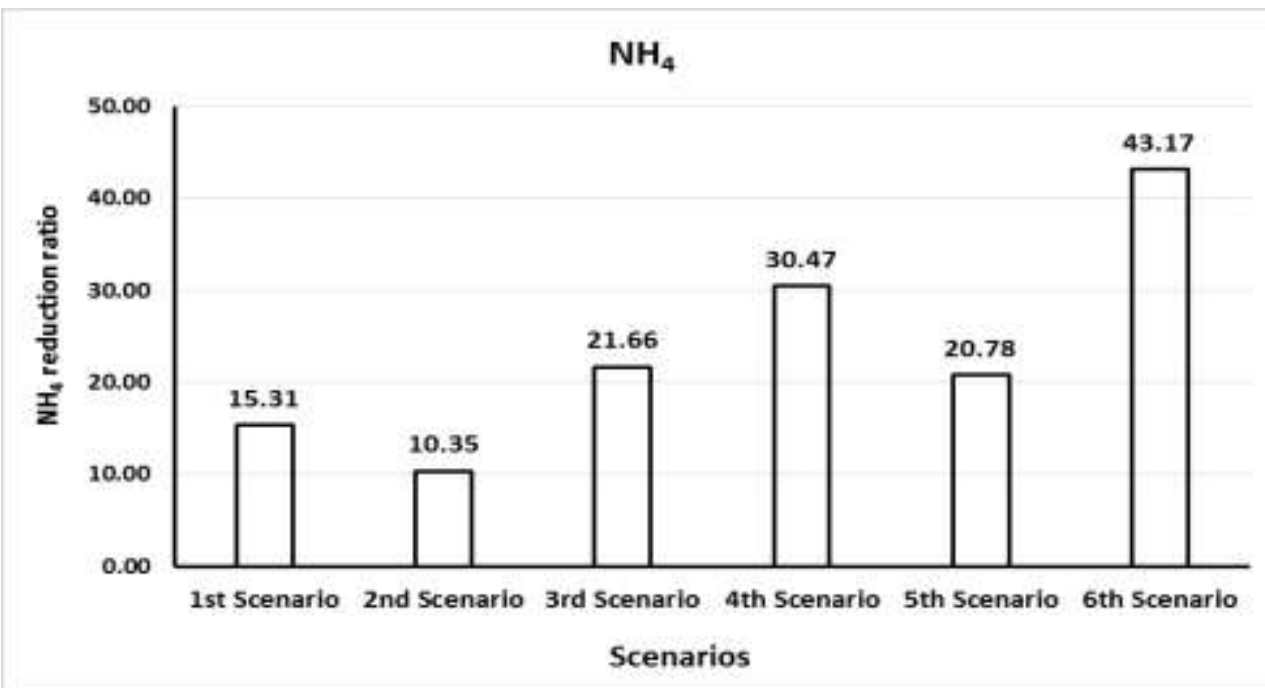

Figure (31): Improvement Ratio of NH4 for the six Scenarios

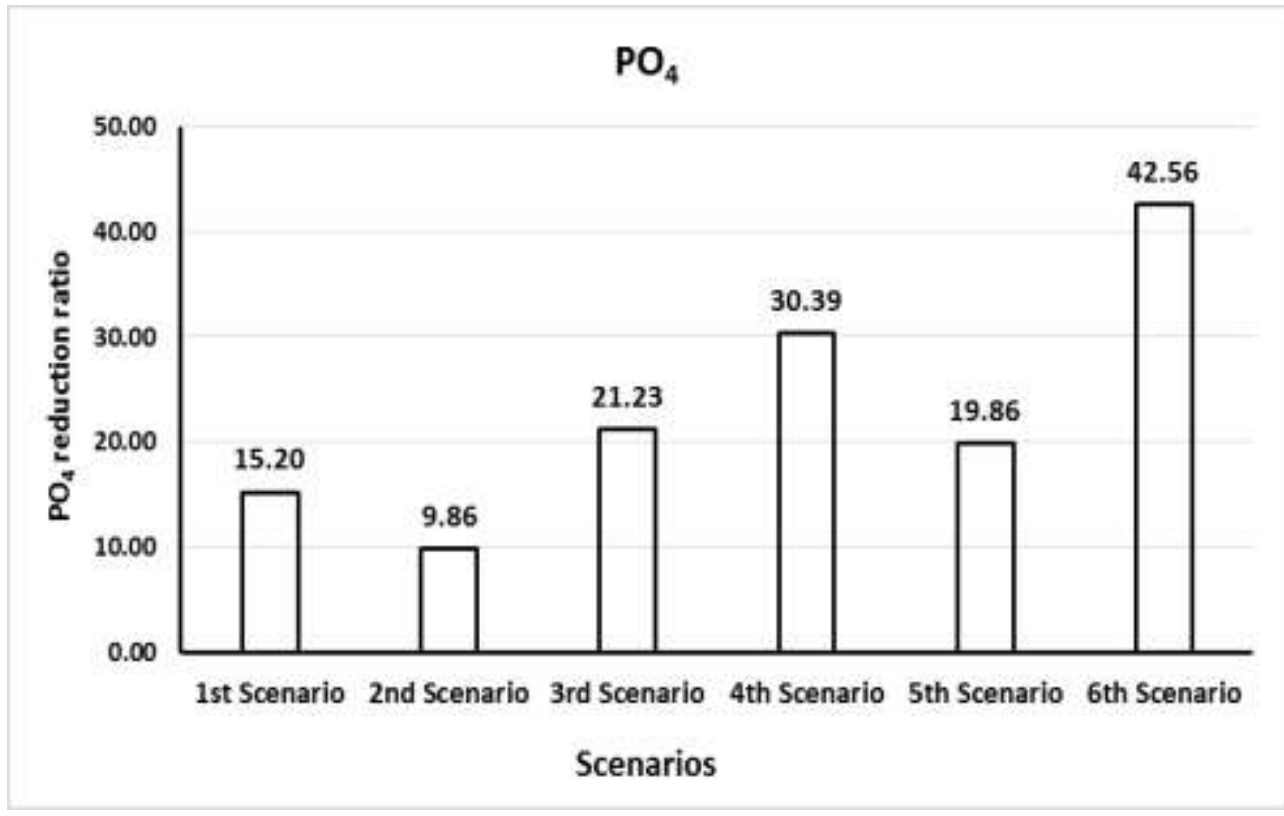

Figure (32): Improvement Ratio of PO4 for the six Scenarios 
The First scenario: is the improvement of the treatment of treatment plants at Samatay and Pump stations (5) catchments thus assumed improving the water quality at the point sourse by $25 \%$. The following changes have been occurred from Samatay pumps station to $\mathrm{km}$ (12) of the drain:

Increase in oxygen concentrations by 7-14\%.

BOD and nitrate concentrations decrease by 9-21\%.

$>$ The decrease in the concentrations of organic nitrogen, ammonia, organic phosphorus and orthophosphate by 9-20\%.

Decreased in the nitrite concentrations by $10-17 \%$.

The Second scenario: is the improvement of treatment of the wastewater stations that are in the catchment of stations 4, 3, 6, which assumed in improving water quality at these point sources by $25 \%$. The following changes occurred from the (6) pump station to $\mathrm{km}$ (12) of the drain:

Increase in oxygen concentrations by 3-9 \% .

BOD, Organic Nitrogen, Ammonia, Nitrate, Organic Phosphorus and Orthophosphate concentrations decreased by $5-13 \%$.

Nitrite concentration decrease by $2-8 \%$.

The Third scenario: is improving the treatment of the wastewater plants that are in the catchment of Samatay, (5, 6, 3 and 4) Pump stations, which assumed to improve water quality at these point sources by $25 \%$. The following changes occurred from Samatay pumps station to $\mathrm{km}$ (12) of the drain:

Increase in oxygen concentrations by $10-15 \%$.

Decreasing in the BOD and nitrate concentrations by $19-23 \%$. 
The decrease in the concentrations of organic nitrogen, ammonia and organic phosphorus by $18-23 \%$.

The decreasing in nitrite concentrations by $16-19 \%$.

The reduction of orthophosphate concentrations by $18-22 \%$.

The Fourth scenario: is the Improving the treatment of the wastewater plants that are in the catchment of Samatay and Pump stations (5), which assumed in improving the water quality of these point sources by $50 \%$. The following changes occurred from Samatay pumps station to $\mathrm{km}(12)$ of the drain:

Increasing in oxygen concentrations by $13-15 \%$.

BOD concentrations decreased by $19-42 \%$.

Decrease in the concentrations of organic nitrogen, ammonia and organic phosphorus by $11-27 \%$.

Nitrite concentrations decrease by $5-17 \%$.

Nitrate concentrations decreases by $11-26 \%$.

The decrease in orthophosphate concentrations by 10-26\%.

The Fifth scenario: is the improvement of the treatment of the wastewater stations that are in the reach of stations $(6,3,4)$, which assumed improve the water quality at these point sources by $50 \%$.

The following changes occurred from the (6) pump station to $\mathrm{km}(12)$ the drain:

Increasing in oxygen concentrations by 7-17 \%.

BOD concentrations decreased by $18-27 \%$. 
Decrease in the concentrations of organic nitrogen, ammonia and organic phosphorus by $11-27 \%$.

Nitrite concentrations decrease by 5-17 \%.

Nitrate concentrations decreases by 11-26\%.

The decrease in orthophosphate concentrations by 10-26\%.

The Sixth scenario: is the improvement of the treatment of the wastewater plants that are in the catchment of Samatay, pump Stations (5, 6, 3 and 4), the assumed improvement of the water quality at these point sources by $50 \%$. The following changes occurred from Samatay pump station to kilo (12) of the drain:

Increasing in oxygen concentrations by $20-27 \%$.

BOD concentrations decrease by $38-46 \%$.

Decreased organic nitrogen concentrations by 36-46\%.

Ammonia concentrations decreased by $37-46 \%$.

Nitrite concentrations decreased by $33-41 \%$.

Nitrate concentrations decreases by $38-46 \%$.

Decreases the concentrations of organic phosphorus by 37-46 \%.

The reduction of orthophosphate concentrations by $37-45 \%$.

The results indicate that the sixth scenario in which $50 \%$ improvement in water quality of the point sources of samatay \& P.S. 3,4,5,6 wastewater treatment plants is the best scenario followed by the fourth (enhancement in the wastewater plants that are in the reach of Samatay and (5) Pump stations, which results in improving the water quality at these stations by 50\%). And fifth scenario which proposes the enhancement in the wastewater treatment plants that are in the catchment of stations $(6,3,4)$ has been improved the 
water quality by $50 \%$. The implementation of these scenarios depends mainly on the provision of financial allocations.

\section{RECOMMENDATIONS}

It is recommended to apply similar study that can be conducted by using two or three-dimensional models in order to facilitate reliable comparison with the current study. Also providing researchers with more accurate data in terms of bathymetric and water quality data will result in better simulation with more understanding the water pollution factors. In this study, the impact of one water quality parameter each time was investigated; therefore, combination of different water quality parameters can be used in the assessment of factors affecting the water quality simulation.

\section{REFERENCES}

APHA (American Public Health Association) 1999: Standard methods for the examination of water and wastewater. $20^{\text {th }} \mathrm{Ed}$.

DRI. (Drainage Research Institute) 1995: Reuse of drainage water in the Nile Delta: monitoring, modelling and analysis. Reuse Report No. 50. Cairo, Drainage Research Institute and Wageningen, the Netherlands, DLO Winand Staring Centre.

DRI. (Drainage Research Institute) 1997a: Drainage water in the Nile Delta: Yearbook 1995/96. Reuse monitoring programme, Report No. 41. Cairo, Drainage Research Institute.

DRI. (Drainage Research Institute) 1997b: Drainage water irrigation project. Final report. Cairo, Drainage Research Institute, Louis Berger International, Inc. and Pacer Consultants. 
DRI (Drainage Research Institute) 2000: Monitoring and Analysis of Drainage Water Quality Project, Drainage Water Status in the Nile Delta Yearbook 97/98. Technical Report No. 52.

NWRP. (National Water Resources Plan) 2005: Water for Future, 2017. Planning Sector, Ministry of Water Resources and Irrigation, Egypt.

William, L. Luyben (1996): Process Modeling, Simulation, and Control for Chemical Engineers International Edition.

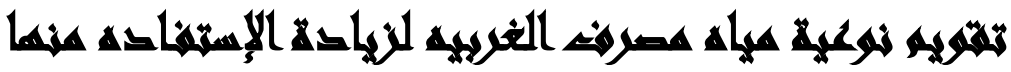

\section{$[\bullet]$}

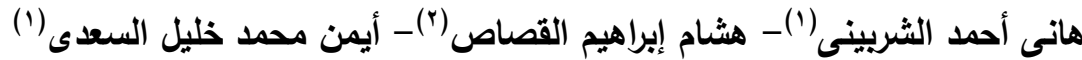

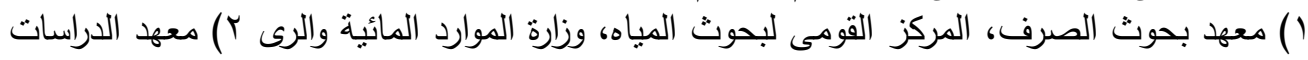
والبحوث البيئية، جامعة عين شمس بهرف

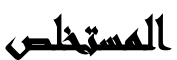

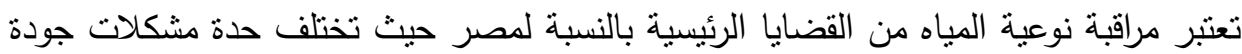

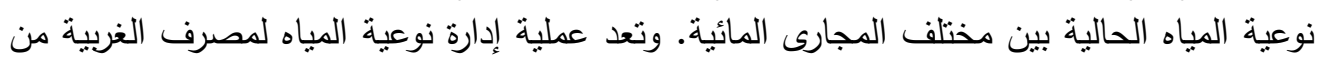

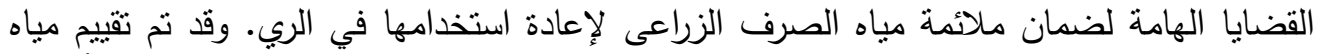
المصرف بشكل كبير باستخدام نموذج محاكاة نوعية المياه (HEC-RAS). وقد الشتملت أنشطة الأنة

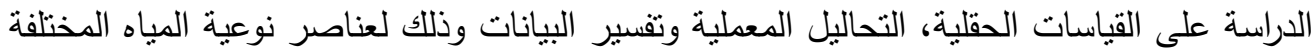

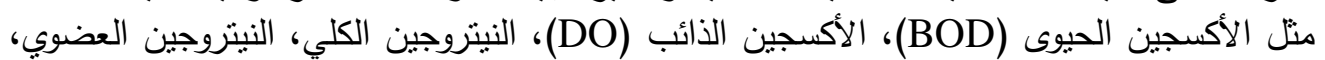

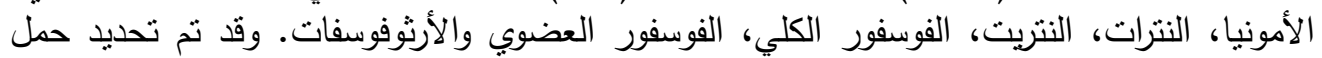

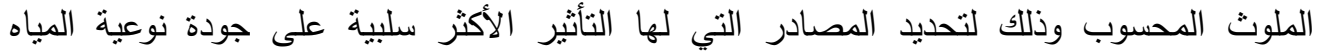

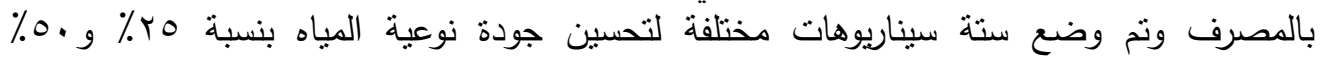

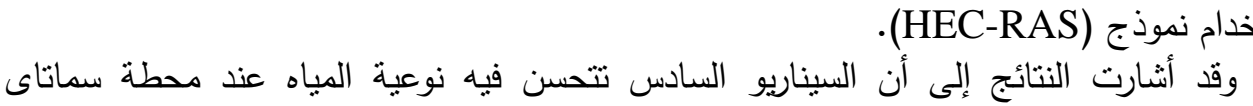

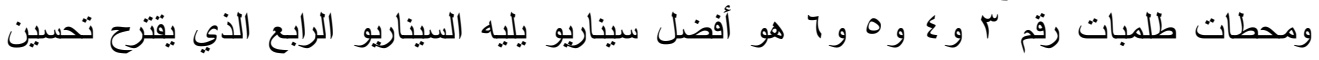

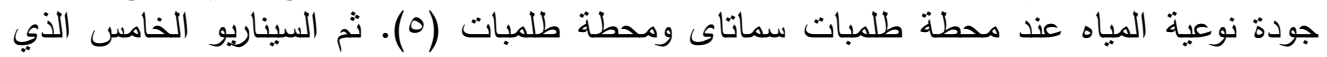
يقترح تحسين جودة نوعية المياه عند محطات طلمبات رقم (ج)، سات، ع). 